\title{
Review of the diversity, traits, and ecology of zooxanthellate jellyfishes
}

\author{
Djeghri Nicolas ${ }^{1,{ }^{*}}$, Pondaven Philippe ${ }^{1}$, Stibor Herwig ${ }^{2}$, Dawson Michael N. ${ }^{3}$
}

1 Univ Brest, Inst Univ Europeen Mer, IUEM UBO, Lab Sci Environm Marin,LEMAR,UMR 6539,

Technopole Brest Iroise,Rue Dumont dUrville, F-29280 Plouzane, France.

${ }^{2}$ Ludwig Maximilians Univ Munchen, Dept Biol 2, Aquat Okol, Grosshaderner Str 2, D-82152 Munich, Germany.

${ }^{3}$ Univ Calif, Sch Nat Sci, Dept Life \& Environm Sci, 5200 North Lake Rd, Merced, CA 95343 USA.

*Corresponding author : Nicolas Djegrhi, email address : nicolas.djeghri@gmail.com

\begin{abstract}
:
Many marine organisms form photosymbioses with zooxanthellae, but some, such as the medusozoans, are less well known. Here, we summarize the current knowledge on the diversity of zooxanthellate jellyfishes, to identify key traits of the holobionts, and to examine the impact of these traits on their ecology. Photosymbiosis with zooxanthellae originated at least seven times independently in Medusozoa; of these, five involve taxa with medusae. While most zooxanthellate jellyfishes are found in clades containing mainly non-zooxanthellate members, the sub-order Kolpophorae (Scyphozoa: Rhizostomeae) is comprised-bar a few intriguing exceptions-of only zooxanthellate jellyfishes. We estimate that $20-25 \%$ of Scyphozoa species are zooxanthellate (facultative symbiotic species included). Zooxanthellae play a key role in scyphozoan life-cycle and nutrition although substantial variation is observed during ontogeny, or at the intra- and inter-specific levels. Nonetheless, three key traits of zooxanthellate jellyfishes can be identified: (1) zooxanthellate medusae, as holobionts, are generally mixotrophic, deriving their nutrition both from predation and photosynthesis; (2) zooxanthellate polyps, although capable of hosting zooxanthellae rarely depend on them; and (3) zooxanthellae play a key role in the life-cycle of the jellyfish by allowing or facilitating strobilation. We discuss how these traits might help to explain some aspects of the ecology of zooxanthellate jellyfishes-notably their generally low ability to outbreak, and their reaction to temperature stress or to eutrophication-and how they could in turn impact marine ecosystem functioning.
\end{abstract}


35 Acknowledgements First we would like to thank Patricia Kremer and Alan Verde who

36 provided some unpublished data on Linuche unguiculata and Cassiopea xamachana

37 respectively. We would also like to thank Ferdinando Boero and André Cararra Morandini for

38 pointing us to some hard to find literature. Finally, we thank Bella Galil, Ilka Straehler-Pohl

39 and Sho Toshino for details about some of their work.

40 We also thank two anonymous reviewers for their valuable comments and suggestions.

41 Finally, we thank Natalia Llopis Monferrer for the artwork in Fig. 3.

43 Funding This work is part of the Ph.D. project of Nicolas Djeghri, funded by the University of 44 Western Britany (UBO). 


\section{Introduction}

Many organisms, from corals and giant clams to protists, form photosymbioses with endosymbiotic, autotrophic dinoflagellates or "zooxanthellae" (Venn et al. 2008; Stoecker et al. 2009). Most of our knowledge on this kind of relationships comes from the study of photosymbiotic scleractinian corals, but other cnidarians also form photosymbioses including jellyfishes (e.g. Arai 1997). Zooxanthellate jellyfishes are historically linked to the study of cnidarian-zooxanthellae symbiosis as the zooxanthellae first described as Symbiodinium was obtained from the upside-down jellyfish Cassiopea (Freudenthal 1962). This jellyfish genus Cassiopea is still relevant today as a model organism (Ohdera et al. 2018) while other symbiotic scyphozoan species have potential to illuminate pelagic symbioses (e. g. Muscatine et al. 1986). Moreover, their relevance is increasing as zooxanthellate jellyfishes' populations have also increased in some environments (Arai 2001; Pérez-Ruzafa et al. 2002) raising the question of their roles in ecosystem functioning (see e.g. Pitt et al. 2009).

However, despite increasing interest, zooxanthellate jellyfish remain little studied relative to other, non-zooxanthellate, jellyfishes or to scleractinian corals. Zooxanthellate jellyfishes are of particular interest for two, often distinct, communities of scientists: the first, focused on jellyfishes, the second focused on photosymbiosis. This has led to a somewhat scattered literature with few works bridging the gap. Our goal with this review is to establish a more integrative, synthetic, foundation for future studies focusing on the diversity and on the ecology of zooxanthellate jellyfishes.

All zooxanthellate jellyfishes share two key characteristics. First a metagenetic life-cycle, as many other, non-zooxanthellate, jellyfishes, with two distinct body-plans and ecologies: the polyp and the medusa (Box 1). Second a photosymbiotic relationship with zooxanthellae, as in scleractinian corals (Box 2). The combination of these two characteristics and their interplay is likely to give zooxanthellate jellyfishes a unique set of ecological traits. Indeed, zooxanthellate jellyfishes have a variety of unique morphologies and behaviors (Arai 1997), a narrower latitudinal distribution (e.g. Holland et al. 2004; Swift et al. 2016), a propensity to not bloom (Dawson and Hamner 2009), and a different nutrition (e.g. Verde and McCloskey 1998; Kremer 2005) from their non-zooxanthellate counterparts. However, these jellyfishes also occupy multiple branches of the cnidarian tree of life. This raises the question of 
whether these characteristics are attributable to the symbiosis itself or to other lineagespecific evolutionary history.

To better understand these characteristics of zooxanthellate jellyfishes, we divide our review into three parts. First, we review the phylogenetic distribution of zooxanthellate jellyfishes. Second, we review the roles of zooxanthellae in zooxanthellate jellyfishes, primarily with respect to their complex life-cycle and in their nutrition. Finally, once the key traits have been characterized, we review how these traits could impact the ecology of zooxanthellate jellyfishes and their influence on marine communities and ecosystem functions.

\section{Box 1: Jellyfishes and their Metagenetic Life-Cycle}

Jellyfish may be seen as an ambiguous word. Here, we refer to jellyfish as pelagic cnidarians (Lucas and Dawson 2014). Many of these organisms display a complex lifecycle with an alternation of a benthic, asexually reproducing, polyp phase and a pelagic, sexually reproducing, medusa phase. Differences in the details of the life-cycle exist between groups. For instance, the transition between the polyp and the medusa phase is generally done by lateral budding in Hydrozoa, by metamorphosis in Cubozoa, and by strobilation in Scyphozoa (see e.g. Boero et al. 2016). Many variations from this general depiction of life-cycles exist; for instance, reduction or loss of one of the phases (very common in Hydrozoa, Bouillon et al. 2006).

The alternation of polyp and medusae phases has important repercussions for the ecology of these organisms. Generally, populations of asexually reproducing polyps are perennial, and represent the source of the pelagic medusae populations. Then, pelagic medusae, may bloom, aggregate, or swarm (see e.g. Lucas and Dawson 2014), with potential for ecological and human consequences. 


\section{Box 2: Cnidarian-Zooxanthellae Photosymbiosis}

Photosymbiosis can be defined predominantly as a mutualistic nutritional association. In the case of the cnidarian-zooxanthellae photosymbiosis the symbionts are found within host cells (endosymbionts). This involves complex processes of symbiont recognition, acquisition and regulation (see Davy et al. 2012). The main advantage of this kind of symbiosis is nutritional. Zooxanthellae photosynthesize and share some of the photosynthates with their host. These photosynthates include diverse molecules such as carbohydrates, lipids and amino-acids that can be metabolized by the host (Davy et al. 2012). The symbionts can then use the host excretion and respiration products $\left(\mathrm{CO}_{2}\right.$, dissolved inorganic nitrogen) for their autotrophic metabolism (Yellowlees et al. 2008, Davy et al. 2012). Consequently, these associations allow a recycling of nutrients within the holobiont (symbionts + host). They are thus considered particularly advantageous in nutrient poor environments (Yellowlees et al. 2008). 


\section{Box 3: Glossary}

We give here some of the technical terms used in this review. For more information on jellyfish anatomy, development and taxonomy, see Arai 1997 and Bouillon et al. 2006.

\section{Ecology:}

Bloom: A true, natural, jellyfish bloom is defined as an increase in jellyfish biomass linked to phenology (see Lucas and Dawson 2014).

\section{Development:}

Planula: The larval stage of cnidarians. Generally pyriform, ciliated, and motile.

Planuloid budding: A mode of asexual reproduction in scyphozoan polyps. A planuloid bud is formed by a polyp, detaches and swims to finally reattach to the substrate and form a new polyp. This is the dominant mode of polyp formation in Kolpophorae, a group of monodisk strobilating, often photosymbiotic, jellyfishes.

Ephyra: Young medusa-like stage in Scyphozoa.

Strobilation: A mode of asexual reproduction whereby a scyphozoan polyp forms ephyrae through transverse fission (see Helm 2018). Strobilation can be monodisc, when one ephyra is formed at a time or polydisc, when multiple ephyrae are formed at the same time.

\section{Anatomy:}

Mesoglea: An extracellular matrix, primarily composed of collagen, located between the endoderm and ectoderm in cnidarian. In medusae, the mesoglea can be thick and generally provides most of the volume of the animal.

Oral arms: In medusae, expansions of the mouth involved in prey capture and, at times, digestion. Not to be confounded with tentacles.

Exumbrella: In medusae, the superior (aboral) part of the umbrella.

Subumbrella: In medusae, the inferior (oral) part of the umbrella.

Coronal muscle: A circular muscle that ensures umbrella contractions. 


\section{Diversity of Zooxanthellate Jellyfishes}

88

\subsection{Diversity of Hosts}

Jellyfish (i.e. pelagic cnidarians, Lucas and Dawson 2014) belong to the taxon Medusozoa. Albeit the aim of this review is to focus on zooxanthellate jellyfishes, their evolutionary history cannot be separated from either: (1) other medusozoans that lack zooxanthellae and, (2) other medusozoans that lack a pelagic phase. Thus, all groups of medusozoans are taken in account, at this first stage, to discuss phylogenetic patterns of zooxanthellate medusozoans (Table 1, Fig. 1).

Considering only confirmed reports of zooxanthellate presence (Table 1), we estimate that symbiosis between medusozoans and zooxanthellae originated independently at least seven times (Fig. 1). Of these seven originations, five involved groups containing pelagic taxa (i.e. jellyfishes) (Fig. 1): one in Cubozoa (two species of Carybdeid jellyfish), two in Hydrozoa (in Capitata with the family Porpitidae and in Loadiceida with the genus Wuvula) and two in Scyphozoa (in Coronatae with the Linuchidae plus some Nausithoe and in Kolpophorae). The two other originations are from hydrozoan groups lacking a medusae phase (see Bouillon et al. 2006): in Filifera I (family Eudendriidae) and in Macrocolonia (e.g. Aglaophenia, Halecium, Pseudoplumaria). No zooxanthellate staurozoans have been found.

It is important to emphasize that seven originations of symbiosis with zooxanthellae in Medusozoa is a minimum. Firstly, symbioses between zooxanthellae and medusozoans are often little documented in the literature. It is thus likely that we have underestimated the number of zooxanthellate species. Secondly, the phylogeny of hydrozoans in particular is more complex than presented here. Thus, some zooxanthellate groups may be subdivided more finely phylogenetically as more data are gathered. For instance, Macrocolonia is a very diversified group (Maronna et al. 2016) and it is likely that the macrocolonian genera reported to be zooxanthellate are not closely related (see Maronna et al. 2016; Moura et al. 2018). Similarly, the Porpitidae family and the genus Millepora (fire corals) both belong to Capitata and host zooxanthellae but might not be closely related (Nawrocki et al. 2010). This remark is also valid for zooxanthellate Coronatae until phylogenetic relationships are better resolved (Fig. 1). Finally, Dichotomia cannoides (Hydrozoa, Leptothecata, Dipleurosomatidae) 
may represent another origination of the medusozoan-zooxanthellae symbiosis. However, until its phylogeny is better resolved (Maronna et al. 2016), it cannot be confirmed.

Despite multiple originations, only a minority of medusozoans are found in symbiosis with zooxanthellae. Often, photosymbiotic species are clustered in mostly non-zooxanthellate clades. Even in close relatives (within a family or a genus) it is common that some species are zooxanthellate while most others are not (see e.g. Aglaophenia - Svoboda and Cornelius 1991, Alatina - Carrette et al. 2014, Eudendrium - Marques et al. 2000, Laodiceidae - Bouillon et al. 2006, Nausithoe - Silveira and Morandini 1997). In these groups, symbiosis with zooxanthellae does not appear to have favored adaptive radiation. In which context, Kolpophorae appears as an exception: it is a diversified group with ca. 40-50 species in five families (Daly et al. 2007) and likely many more yet to be described (Gómez Daglio and Dawson 2017), that is predominantly, and possibly only, constituted of zooxanthellate species. Six of the nine genera of Kolpophorae are reported to be zooxanthellate, photographic evidence suggest that two other genera might have zooxanthellae (ESM 1). We hence infer parsimoniously that all Kolpophorae might be zooxanthellate (facultative included; Table 1).

Considering all Kolpophorae plus the zooxanthellate Coronatae we estimate that between 20 and $25 \%$ of scyphozoan species are zooxanthellate (including facultative symbionts, species richness obtained from Daly et al. 2007). Such an estimate is hard to give at present for hydrozoans and cubozoans as their zooxanthellate representatives are less documented. 


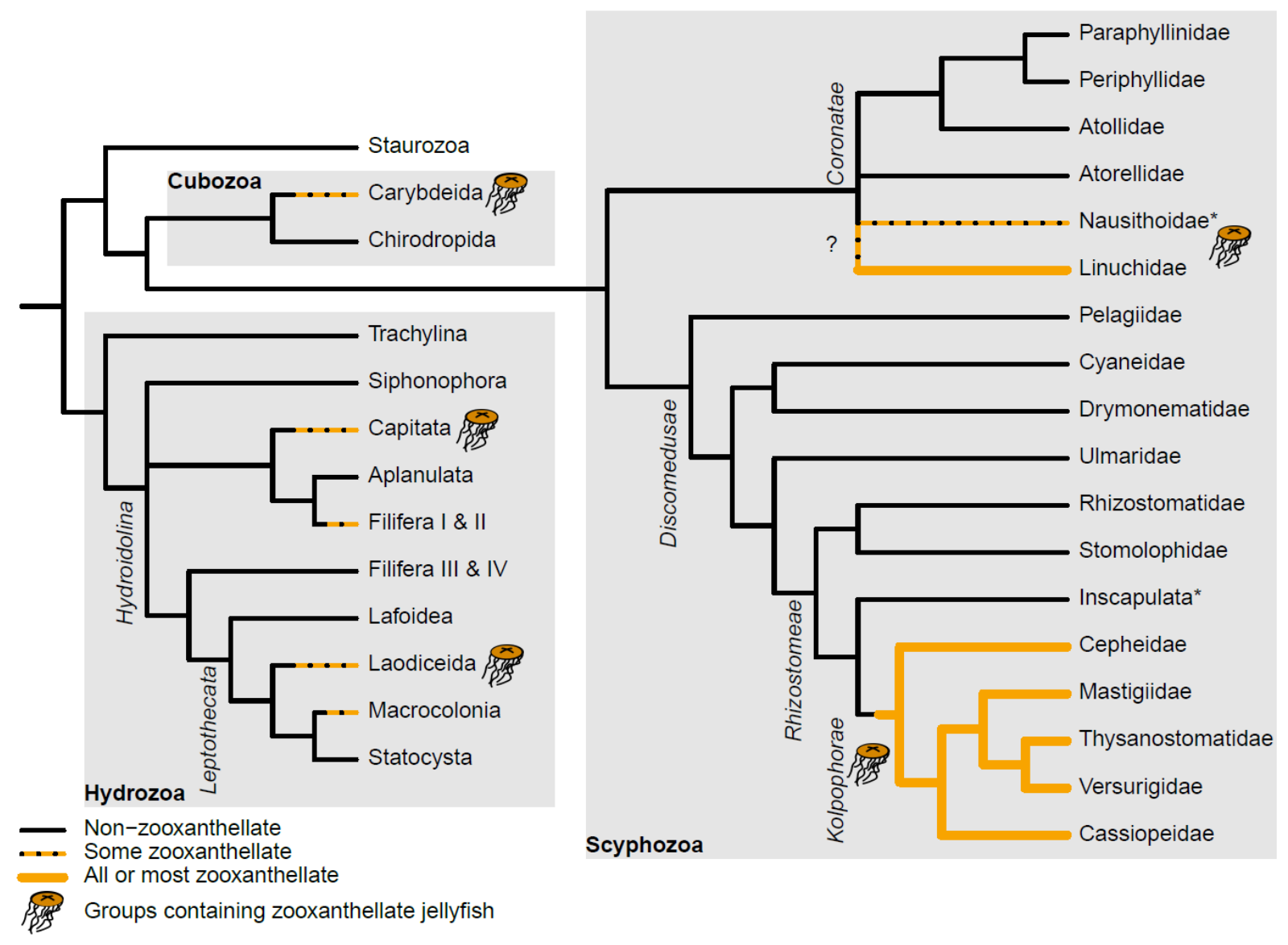

139 Fig. 1 Phylogenetic position of zooxanthellate medusozoans with emphasis on Scyphozoa.

140 The topology used here is based on Kayal et al. (2018) for the relationships among major groups, Kayal et al. (2015) for Hydroidolina, Maronna et al. (2016) for Leptothecata, Bayha et al. (2010) for Coronatae and Gómez Daglio and Dawson (2017) for Discomedusae. ' ${ }^{* \prime}=$ nonmonophyletic group. '?' = unclear origin of symbiosis with zooxanthellae in Coronatae. See Table 1 for the literature identifying zooxanthellae presence. Only confirmed reports are taken into account in this figure with the exception of Kolpophorae where we parsimoniously infer the presence of zooxanthellae in all or most species (possibly facultative, see ESM 1)

\subsection{Diversity of Symbionts}

150 Zooxanthellae associated with jellyfish species belong mostly to the family Symbiodiniaceae

151 (see the recent revision of the family, LaJeunesse et al. 2018). The most common symbionts

152 found in zooxanthellate scyphozoan jellyfishes in the field appear to belong to the genera

153 Symbiodinium (previously Symbiodinium clade A) and Cladocopium (previously 
Symbiodinium clade C) although other Symbiodiniaceae can be found (LaJeunesse et al. 2001; Santos et al. 2003; Thornhill et al. 2006; Mellas et al. 2014). Furthermore, laboratory experiments have demonstrated that the associations between the jellyfish Cassiopea spp. and Symbiodiniaceae genera are not specific. Indeed, Cassiopea spp. polyps have been successfully infected with a variety of isolated and mixed Symbiodiniaceae genera including Symbiodinium, Cladocopium, Breviolum (previously Symbiodinium clade B) and Durusdinium (previously Symbiodinium clade D) (Thornhill et al. 2006; Mellas et al. 2014; Lampert 2016). However, adult medusae tend to harbour only one phylotype of symbiont suggesting that a mechanism such as competitive exclusion occurs within the host (Thornhill et al. 2006). Thus some flexibility appears to exist in the zooxanthellae-jellyfish association. This is further illustrated by the symbionts found in the hydrozoan Velella velella. Zooxanthellae from Velella velella can indeed belong to Symbiodiniaceae (LaJeunesse et al. 2001) but they can also belong to the genera Brandtodinium and Scrippsiella (or Ensiculifera) from the family Thoracosphaeraceae (Banaszak et al. 1993; Probert et al. 2014).

\subsection{Biogeography and Habitat}

Generally, zooxanthellate jellyfishes are found in tropical and sub-tropical waters between $40^{\circ} \mathrm{N}$ and $40^{\circ} \mathrm{S}$ (see e.g. Bieri 1977; Bouillon et al. 1988; Bolton and Graham 2004; Holland et al. 2004; Bayha and Graham 2014; Heins et al. 2015; Straehler-Pohl and Toshino 2015; Boero et al. 2016; Swift et al. 2016). The zooxanthellate coronates and kolpophoran rhizostomes in particular are tropical clades (Dawson and Hamner 2009). However, exceptions can exist as some zooxanthellate jellyfishes may be found in temperate waters either occasionally (e.g. Purcell et al. 2012a) or possibly as resident species (see BrinckmannVoss and Arai 1998).

At finer geographic scales, zooxanthellate jellyfishes are typically shallow-water species (Dawson and Hamner 2009). They have been reported in a number of coastal habitats including lagoons, estuaries, coral reefs, mangroves or marine lakes (see e.g. García 1990; Kikinger 1992; Fleck and Fitt 1999; Pitt et al. 2004; Swift et al. 2016; Morandini et al. 2017). Such coastal habitats are most likely linked to the fact that most zooxanthellate jellyfishes have a benthic polyp phase, which limits their extension toward the open ocean. However, 
the medusa phase in some instances has been reported in the open sea (e.g. in Cepheidae Tokioka et al. 1964; Boero et al. 2016, in Linuche - Larson 1992). Furthermore, hydrozoans of the family Porpitidae realize their whole life-cycle in the open ocean (Bieri 1977), exemplifying that the presence of benthic polyps in the life-cycle, rather than symbiosis with zooxanthellae, more likely restricts jellyfishes to coastal waters.

\section{Roles of the Zooxanthellae in Jellyfish Symbioses}

\subsection{Acquisition, Location, Transmission and Abundance of Zooxanthellae along the} Jellyfish Life-Cycle

\subsubsection{Acquisition of the zooxanthellae}

The acquisition of zooxanthellae is the first step of the symbiosis. A host may acquire zooxanthellae by two means: (1) vertical transmission, where the symbiont is directly transferred from the parents to the offspring (usually from the mother to the egg), or (2) horizontal transmission, where the symbiont is taken from the environment. While vertical transmission may occur in zooxanthellate hydrozoans (see e.g. Mangan 1909; Bouillon 1984; Lewis 1991), it is likely that most other zooxanthellate jellyfishes acquire their symbionts via horizontal transmission. In Kolpophorae, the symbiont is not provided by parents but acquired from the environment at the polyp stage (e.g. Sugiura 1963; Ludwig 1969; Sugiura 1969; Fitt 1984; Colley and Trench 1985; Kikinger 1992; Astorga et al. 2012; Newkirk et al. 2018). The coronate Linuche unguiculata presents a somewhat intermediate mode of acquisition of the symbiont since fertilized eggs are released in mucus strand replete with maternal zooxanthellae that contaminate the larvae very early in development, generally before the 128 cells stage (Montgomery and Kremer 1995).

\subsubsection{Location of zooxanthellae in jellyfishes}

In hydromedusae, zooxanthellae are found in endodermal cells (Bouillon et al. 1988; Banaszak et al. 1993; see also Brooks 1903; Brinckman-Voss and Arai 1998, Fig. 2a). In 
scyphozoans, zooxanthellae first enter polyps' endodermal cells, which then migrate and become mesogleal amaebocytes (Colley and Trench 1985, Fig. 2a and b). In ephyrae, these amaebocytes filled with zooxanthellae stay mostly closely associated with the endoderm (see Kikinger 1992; Silveira and Morandini 1998; Straehler-Pohl and Jarms 2010). This remains the case for later stage medusae in the Coronatae (Linuche unguiculata; Costello and Kremer 1989), and in the Cepheidae (Cotylorhiza tuberculata; Kikinger 1992). In other, non-cepheid, Kolpophorae, the zooxanthellae end up closely associated with the ectoderm (e.g. coronal muscle, subumbrella, exumbrella, oral arms; Blanquet and Riordan 1981; Muscatine et al. 1986; Blanquet and Phelan 1987; Estes et al. 2003; Souza et al. 2007; Fig. 2c). This suggests that the close association of zooxanthellae with the ectoderm could be a synapomorphy of the clade of non-cepheid Kolpophorae. The reason for this evolution is unclear, but perhaps could have adaptive value in allowing better exposure of zooxanthellae to light or nutrients, or providing energy more directly to the host tissues that require it the most.

\subsubsection{Abundance and transmission of the zooxanthellae during the jellyfish life-cycle}

Zooxanthellae abundance in their hosts is affected by the complex life-cycles of jellyfishes. In the best studied zooxanthellate jellyfishes, the Kolpophorae, the symbionts are taken up at the polyp stage. At this stage, the abundance of zooxanthellae can range from zero (aposymbiotic polyp) to tens of thousands of zooxanthellae per polyp (Newkirk et al. 2018). Polyps form other polyps asexually through a variety of processes (e.g. Schiariti et al. 2014) and in Kolpophorae, the dominant process is by far the production of planuloid buds (Schiariti et al. 2014; Heins et al. 2015). During this process, zooxanthellae are transferred from the parent polyp to the forming bud. Thus polyps formed asexually by zooxanthellate polyps are also zooxanthellate (e.g. Sugiura 1964; Ludwig 1969; Silveira and Morandini 1998; Heins et al. 2015). Then, during strobilation, zooxanthellae multiply in the oral region of the polyp where the ephyra is formed (Ludwig 1969). The ephyrae formed are thus also zooxanthellate (e.g. Sugiura 1964; Ludwig 1969; Sugiura 1969; Kikinger 1992; Silveira and Morandini 1997, 1998; Straehler-Pohl and Jarms 2010). Finally, during the growth of medusae, zooxanthellae densities tend to stay constant or to decrease slightly in most species (densities in the order of $10^{7}$ cells. ${ }^{-1}$ wet mass, see Muscatine et al. 1986; Kremer et 
al. 1990; Verde and McCloskey 1998). However, some species such as Cephea cephea may

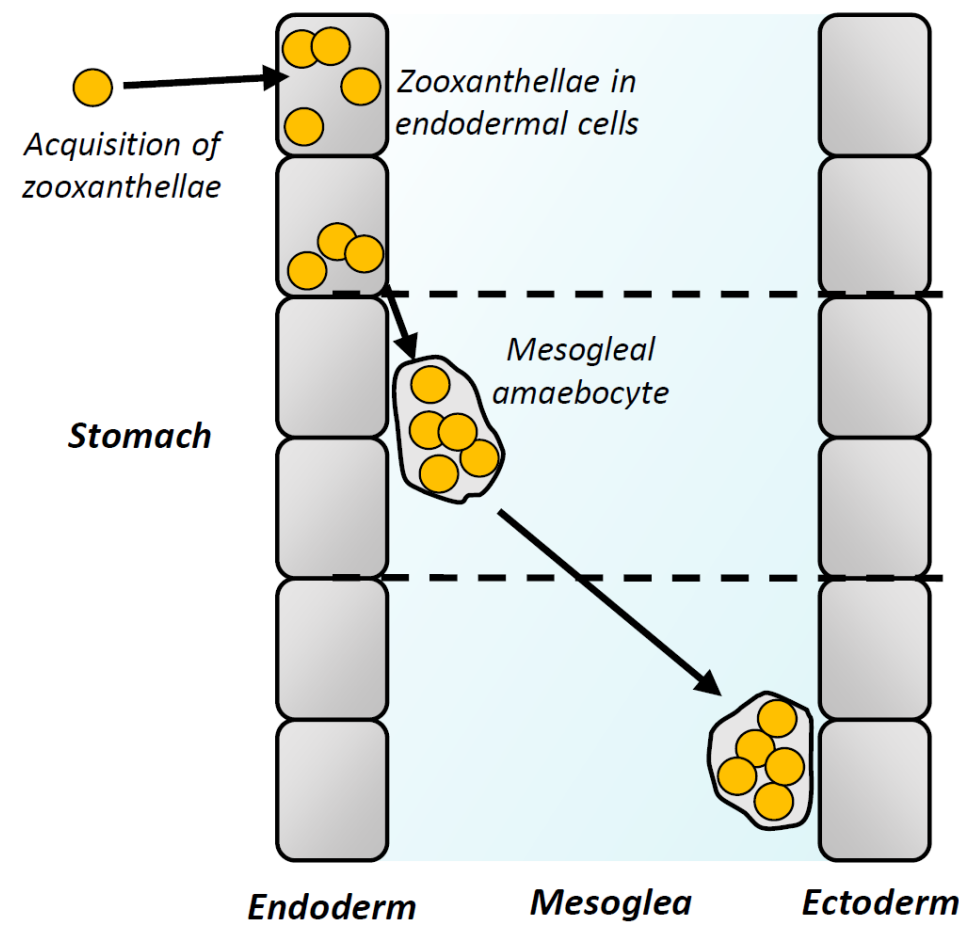
zooxanthellate jellyfish have been compiled in Table 2 . lose their zooxanthellae at the medusae stage (Sugiura 1969); this is likely the case of many other Cepheidae too (see ESM 1). The ontogenic loss of zooxanthellae suggests that the symbiosis might present trade-offs and might not always be advantageous (see e.g. Lesser et al. 2013). The presence or absence of zooxanthellae during the life-cycle of some

(a) Entry of zooxanthellae in endodermal cells (Hydrozoa \& Scyphozoa)

(b) Some endodermal cells become amaebocytes (Scyphozoa) (c) The amaebocytes migrate toward the ectoderm (non-cepheid Kolpophorae)

\section{External} Environment

Fig. 2 Positions of zooxanthellae in jellyfishes' tissues as a function of taxa and ontogeny. (a) Zooxanthellae enter in endodermal cells. (b) Some endodermal cells filled with zooxanthellae become mesogleal amaebocytes. (c) The mesogleal amaebocytes migrate toward the ectoderm at the medusae stage in non-cepheid Kolpophorae. In brackets are the taxa that perform a given step

\subsection{Nutrition of Zooxanthellate Jellyfishes}

\subsubsection{Photosynthesis}

Zooxanthellate jellyfishes differ from non-zooxanthellate jellyfishes by the additional energy source they can access through the photosynthesis of their zooxanthellae (either through 
exchange of metabolites but also through digestion of zooxanthellae, see Davy et al. 2012). In polyps however, only a small part of photosynthates is directed to the host (Hofmann and Kremer 1981). At the medusae stage, by contrast, photosynthesis can constitute an important, if not the major part, of the nutrition of zooxanthellate medusae. Photosynthetic rates are often equal or superior to respiration rates (Drew 1972; Cates 1975; Mergner and Svoboda 1977; Kremer et al. 1990; Kikinger 1992; McCloskey et al. 1994; Verde and McCloskey 1998; Welsh et al. 2009; Jantzen et al. 2010). This indicates that in most cases, respiration requirements in carbon may be fulfilled, and even exceeded, by the photosynthetic activity.

When the holobiont's photosynthesis rates exceed respiration rates, the host's metabolites cannot fulfill the photosynthetic demand of zooxanthellae. Thus zooxanthellate jellyfishes must take additional inorganic nutrients (inorganic carbon, nitrogen or phosphorus) from the surrounding water (reviewed in Pitt et al. 2009; see Hofmann and Kremer 1981; Muscatine and Marian 1982; Wilkerson and Kremer 1992; Pitt et al. 2005; Todd et al. 2006; Welsh et al. 2009; Jantzen et al. 2010; Freeman et al. 2016). Uptake rates of various nutrients can be influenced by some environmental factors. For instance, darkness can induce net nitrogen excretion (Cates and McLaughlin 1976; Pitt et al. 2005; Welsh et al. 2009 but see Muscatine and Marian 1982; Wilkerson and Kremer 1992), while light has been found to increase ammonium and inorganic carbon uptake (Jantzen et al. 2010; Freeman et al. 2016). All this indicates that photosynthetically active zooxanthellae play an important role in inorganic nutrient uptake.

Given the nutritional importance of the symbionts, it is not surprising that their hosts present some behavioral and morphological characteristics that help their zooxanthellae (see e.g. Furla et al. 2011 for scleractinian corals). Zooxanthellate jellyfishes, for instance, tend to maximize their light exposure by swimming near the surface (e.g. Hamner et al. 1982; Larson 1992; Haddad and Nogueira Júnior 2006 but see Bieri 1977), but also by performing more complex horizontal and vertical daily migrations (Hamner and Hauri 1981; Hamner et al. 1982; Dawson and Hamner 2003). Similarly, zooxanthellae patches found in Linuche unguiculata tissue contract with a daily rhythm (Costello and Kremer 1989). One consequence of these behaviors is high exposure to potentially damaging UV radiation. It has thus been hypothesized that some zooxanthellate jellyfishes' pigments might have a 
photoprotective role (Blanquet and Phelan 1987; Dawson 2005 but see Lampert et al. 2012)

292 as might small behavioral adjustments of depth (Dawson and Hamner 2003). Others behavioral and morphological characteristics of zooxanthellate medusae have been suggested to help their zooxanthellae to access inorganic nutrients. For instance, zooxanthellae within their hosts are found in high concentration near the coronal muscle, which is an important source of excretion products (Blanquet and Riordan 1981; Muscatine et al. 1986; Blanquet and Phelan 1987). The zooxanthellate jellyfish Mastigias papua performs reverse diel vertical migrations which help it to access deep nutrients at night (Hamner et al. 1982; Muscatine and Marian 1982), possibly imprinting a daily rhythm in the cell division of its symbionts (Wilkerson et al. 1983). And finally, the pumping action of Cassiopea facilitates its access to nutrient-rich pore water (Jantzen et al. 2010). Additional access to nitrogen might also be provided by symbiotic nitrogen fixing bacteria (Freeman et al. 2017).

\subsubsection{Predation}

Zooxanthellate jellyfishes are predators that can eat a variety of prey. Both the polyp and the medusae stages do feed on zooplankton. Information on the polyp diet in the field is scarce, but they are routinely fed zooplankton such as Artemia sp. nauplii in the laboratory (e.g. Schiariti et al. 2014). In zooxanthellate medusae, it has been suggested that some of the characteristics that favor their autotrophy might be detrimental to their heterotrophy (Arai 1997). An extreme case might be the modified body shape of the benthic Cassiopea sp., which might reduce its contact efficiency with prey as compared to other rhizostomes (see Bezio et al. 2018). For planktonic zooxanthellate jellyfishes, behaviors such as a reversed diel vertical migration might induce spatial mismatch with zooplanktonic prey during the day (Hamner et al. 1982). Zooxanthellate medusae might also have less stinging ability than nonzooxanthellate medusae from other species (Peach and Pitt 2005), or even nonzooxanthellate conspecifics (Bolton and Graham 2004), possibly affecting the amount of captured prey. However, zooxanthellate medusae have been found to feed on a large variety of prey from large diatoms to fish larvae (see e.g. Kikinger 1992; Larson 1997; Pérez-Ruzafa et al. 2002; Graham et al. 2003; Kremer 2005; Peach and Pitt 2005; Purcell et al. 2012a; Zeman et al. 2018). Moreover, the clearance rates of zooxanthellate jellyfishes are often 
comparable to those of similarly sized non-zooxanthellate jellyfishes (García and Durbin 1993; Santhanakrishnan et al. 2012; Bezio et al. 2018). Finally, while several studies indicate that photosynthesis can provide most if not all the carbon requirement, predation seems necessary to meet nitrogen and phosphorus requirements (Kremer 2005; Welsh et al. 2009).

\subsection{Variability in the Roles of Zooxanthellae in Jellyfish Symbioses}

In previous sections we noted that the abundance and position of zooxanthellae can vary during the jellyfish life-cycle or as a function of the jellyfish species (Table 2). In terms of nutrition, zooxanthellate jellyfishes appear to be generally mixotrophic deriving their nutrition from both photosynthesis and predation. However, variations of the relative importance of autotrophy versus heterotrophy can be identified. This variability can be detected along the ontogeny of jellyfishes but also at the intra- and inter-specific level, particularly at the medusae stage.

\subsubsection{Reduced role of zooxanthellae at the polyp stage}

At the polyp stage, the zooxanthellae transmit only a small fraction of the photosynthates to the host (Hofmann and Kremer 1981). Most studies also show that zooxanthellae presence or activity have little impact on polyp's budding or survival (Sugiura 1963; Hofmann et al. 1978; Rahat and Adar 1980; Prieto et al. 2010; but see Mellas et al. 2014). Moreover, the zooxanthellae Durusdinium (previously Symbiodinium clade D) can increase the mortality of Cassiopea sp. polyps (Lampert 2016). All this suggests that, at the polyp stage, symbionts and autotrophy are of little direct importance for most zooxanthellate jellyfishes. However, zooxanthellae in polyps can still provide some benefits for the host such as resistance to hypoxia or acidification (Klein et al. 2017). Such reduced importance of zooxanthellae has also been reported for coral larvae, indicating that importance of the symbiosis can vary through host life-cycle (Hartmann et al. 2019).

This limited importance of zooxanthellae for polyps is further confirmed by the ecology of zooxanthellate jellyfish polyps in the field. Zooxanthellate jellyfish polyps tend to be found more often on the undersides of surfaces (Kikinger 1992; Fleck and Fitt 1999; see also 
Astorga et al. 2012) and the settlement of planulae appears favored in the dark (Duarte et al. 2012). These observations indicate that the polyps are generally poorly exposed to sunlight in the field.

\subsubsection{Important, but still unclear, role of zooxanthellae during strobilation}

Several environmental cues control the strobilation in scyphozoans but one of the most important is temperature (Lucas et al. 2012). This is also true of zooxanthellate scyphozoans (Sugiura 1965; Sugiura 1969; Rahat and Adar 1980; Rippingale and Kelly 1995; Prieto et al. 2010; Purcell et al. 2012b). However, zooxanthellae appear also involved in the strobilation process. Indeed, zooxanthellae tend to multiply and accumulate into the forming ephyra during strobilation (Ludwig 1969). Several laboratory studies show that the presence of zooxanthellae helps, and is even often indispensable, for the onset of strobilation (Sugiura 1964; Ludwig 1969; Sugiura 1969; Hofmann et al. 1978; Rahat and Adar 1980; Hofmann and Kremer 1981, Fitt 1984; Colley and Trench 1985; Kikinger 1992; see also Hofmann et al. 1996 and Astorga et al. 2012) though exceptions apparently exist (e.g. Dawson et al. 2001). Interestingly, zooxanthellae still favor strobilation when they are unable to photosynthesize (Sugiura 1969; Hofmann and Kremer 1981; Hofmann et al. 1996) and time to strobilation is independent of zooxanthellae density in Cassiopea xamachana (Newkirk et al. 2018). This suggests that the role of zooxanthellae during strobilation is not only to provide photosynthates (Hofmann et al. 1996). However, their exact role is still unclear and warrants further research.

\subsubsection{Variable role of zooxanthellae during the medusa stage}

At the medusa stage there can be important variation in the relative importance of autotrophy and heterotrophy among populations or individuals of the same species. The most extreme case may be Phyllorhiza punctata where some populations have zooxanthellae while others do not (Bolton and Graham 2004). Similarly, individuals or populations of Mastigias papua can occasionally be non-zooxanthellate (Dawson et al. 2001). Beyond these extreme cases, it is expected that variations in the autotrophy/heterotrophy balance can vary depending on physiologic (e.g. abundance of 
zooxanthellae) or environmental (e.g. light exposure, availability of prey) conditions. For instance, populations of Mastigias papua appear to differ in the proportion of their energetic demand that can be met by their zooxanthellae (McCloskey et al. 1994). However, few comparative data exist to confirm this point. Individual size can also impact the relative importance of heterotrophy and autotrophy. In some species, the photosynthesis can increase faster than the respiration with medusae size suggesting that larger individuals are more autotrophic than small ones (McCloskey et al. 1994). On the other hand, some other species such as Cephea cephea can lose their symbionts at some point in their development (Sugiura 1969) suggesting that smaller individuals rely more on their zooxanthellae than large ones.

Variation in reliance on zooxanthellae can also be seen inter-specifically. Some species appear to be heavily dependent on their zooxanthellae such as Cassiopea spp. (e.g. low level of light can induce shrinking; Mortillaro et al. 2009). At the other extreme, Cephea cephea (and probably many Cepheidae, ESM 1) may lose its symbionts at the medusae stage (Sugiura 1969) and becomes then strictly heterotrophic. The fact that both zooxanthellate and non-zooxanthellate individuals and populations can be found in Mastigias papua and Phyllorhiza punctata (Dawson et al. 2001; Bolton and Graham 2004) leads us to hypothesize that Kolpophorae are generally ordered Cassiopeidae $>$ Mastigiidae $>$ Cepheidae from the most to the least dependent on zooxanthellae. However, this hypothesized order stays speculative as relevant information exists for only a limited number of species.

\section{From the information compiled here, it is possible to summarize the life-cycle of} Kolpophorae, indicating the transmission, and variation of the role of zooxanthellae (Fig. 3). Due to the little information available it is however impossible to propose such a synthetic view for zooxanthellate cubozoans or hydrozoans. 


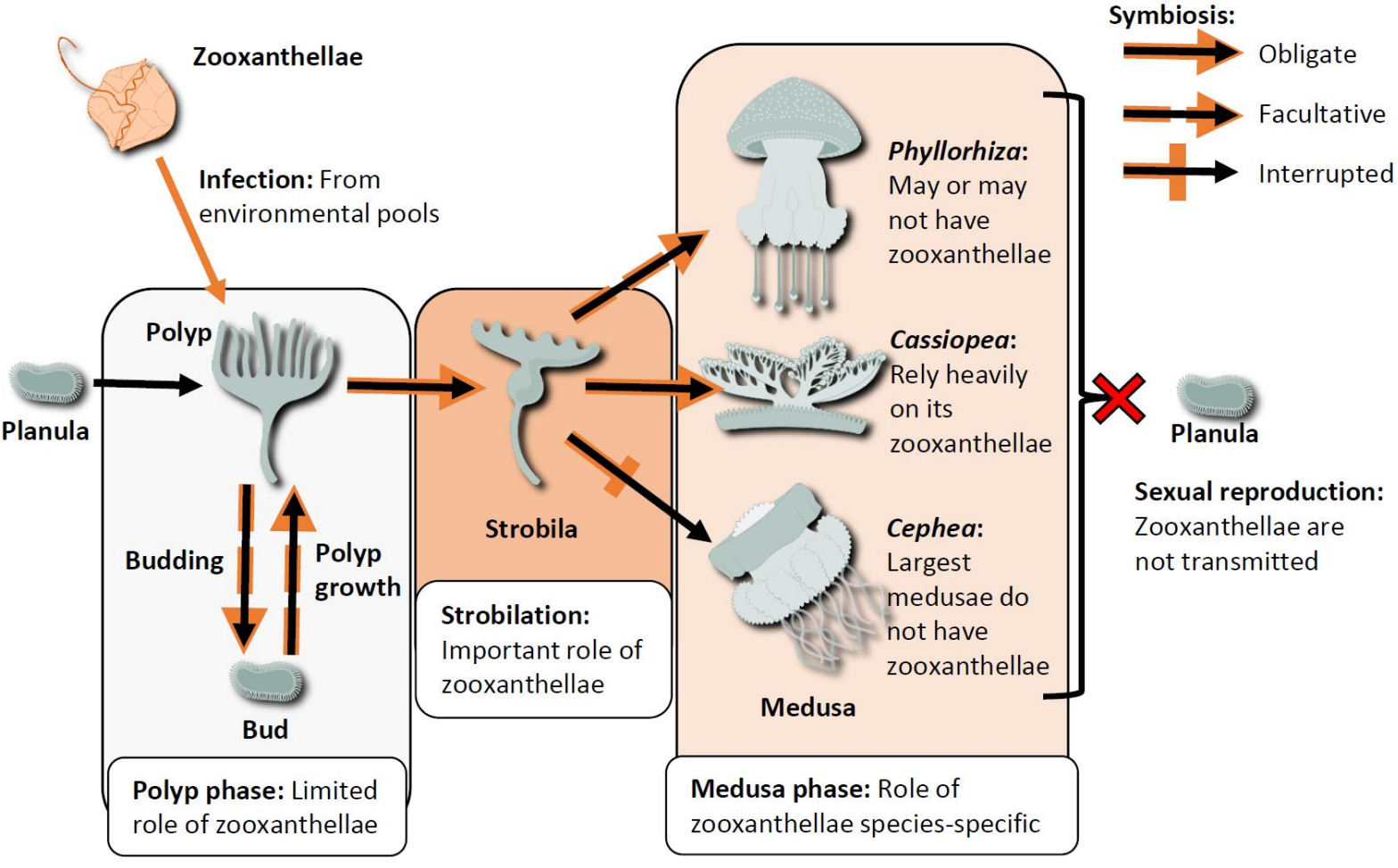

Fig. 3 Synthetic representation of zooxanthellate Kolpophorae (Scyphozoa: Rhizostomeae) life-cycle with presence and importance of zooxanthellae. Black arrows indicate jellyfish lifecycle while orange arrows indicate presence of the symbiont. The infection occurs at the polyp stage. The symbiont is transmitted during asexual reproduction (budding and strobilation) but not during sexual reproduction. Symbionts are generally important for strobilation but not for budding. During the medusae phase, the nutritional importance of the symbiont is species specific (three examples are given)

\subsection{Zooxanthellate Jellyfishes as a Unique Combination of Traits}

Although evolution is typically considered to proceed through the gradual acquisition of small modifications, the evolution of photosymbioses in the jellyfishes combined traits that previously were present only in very distinct lineages. The novel zooxanthellate jellyfishes thus can be compared and contrasted with other groups of cnidarians-non-zooxanthellate jellyfishes, and photosymbiotic scleractinian corals-with which they share newly assorted characteristics. The novel combination brought together (1) the complex life-cycle, the bodyplan, and the mobility of the former with (2) the often oligotrophic, shallow-water, photosymbiosis of the latter. We believe that the integration, in zooxanthellate jellyfishes, of 
these two characteristics became more than the sum of the parts: this unique combination of complex traits originated three major novelties in the ecologies of zooxanthellate jellyfishes.

Large pelagic mixotrophs: The combination of the medusa and photosymbiosis not only conjoined a pelagic life-style with mixotrophy, but additionally did so in relatively large and fast growing, annual, organisms. Other pelagic photosymbioses are found in protists (Stoecker et al. 2009), but zooxanthellate jellyfishes are orders of magnitudes larger; corals in contrast, are benthic, perennial and slow growing. In this regard, zooxanthellate jellyfishes occupy a unique ecological niche, which, for some (especially Kolpophorae), may have represented a new adaptive zone (sensu Simpson 1953).

Heterotrophic benthic photosymbioses: In spite of their ability to host zooxanthellae, zooxanthellate jellyfish polyps generally do not rely much on them. They can thus be seen as (mostly) heterotrophic benthic photosymbioses, in stark contrast to the mixotrophic benthic corals. One can speculate on why it is the case. Scyphozoan polyps are generally found on undersides of surfaces (e.g. Arai 1997) where they are not exposed to light and zooxanthellate jellyfish polyps may simply have retained this trait from their nonzooxanthellate ancestors. Irrespective of the reason, this implies that the polyp would most likely behave more as a non-zooxanthellate jellyfish polyp than as a small scleractinian coral.

A symbiont-dependent strobilation: The strobilation process in zooxanthellate jellyfishes is facilitated or permitted by the symbionts. The underpinning process is still unknown but it is not only due to energetic requirements. This may be due to the fact that the medusae needs the symbionts more than the polyp but cannot acquire them; that the polyp is not competent to strobilate without zooxanthellae assures that the medusae would have the symbionts. Irrespective of the mechanism, this implies that the transition from the polyp to the medusa is under the control of a supplementary factor as compared with nonzooxanthellate jellyfishes.

These three novel complex traits are likely shared to differing degrees by different zooxanthellate jellyfishes. They are most characteristics of the large zooxanthellate scyphozoans (e.g. Cassiopea, Mastigias) from which most of the data were gleaned. 
Exploring the extent to which these conclusions can be applied to other, less studied, zooxanthellate hydrozoan and cubozoan jellyfishes is a key research agenda.

\section{Ecology of Zooxanthellate Jellyfishes}

The unique combination of traits found in zooxanthellate jellyfishes is expected to shape various aspects of their ecology. Notably, differences in strobilation, nutrition and dependencies on environmental conditions might impact their population dynamics as compared to non-zooxanthellate jellyfishes. Likewise, differences in life-cycle or nutrition might impact the way zooxanthellate jellyfishes react to environmental perturbations as compared with non-zooxanthellate jellyfishes or corals. Finally, their unique combination of traits could lead to unique impacts on marine ecosystems and communities.

\subsection{Population Dynamics}

\subsubsection{Phenology}

Across their range of habitats, zooxanthellate jellyfishes can exhibit varied phenology. In some cases, medusae are present year-round (Hamner and Hauri 1981; Hamner et al. 1982; Fitt and Costley 1998) sometimes with mixed size-classes, suggesting long or continuous recruitment periods. Contrastingly, in other environments, the medusae are present seasonally (García 1990; Pérez-Ruzafa et al. 2002; Pitt et al. 2004; Purcell et al. 2012b) with generally one cohort identifiable each year (e.g. Ruiz et al. 2012). On top of these intraannual population fluctuations, recruitment differences (Ruiz et al. 2012) or long term environmental variations such as El Niño Southern Oscillation (Dawson et al. 2001; Martin et al. 2006) can shape populations sizes over years or decades. Such phenology and population fluctuations are also observed in non-zooxanthellate jellyfishes (e.g. Dawson and Martin 2001; Purcell et al. 2012b; Condon et al. 2013).

\subsubsection{Blooming ability}


An important aspect of many jellyfish species population dynamics is their tendency to bloom (Dawson and Hamner 2009; Lucas and Dawson 2014). Blooms are defined as sudden increases of medusa biomass linked with seasonal life-cycle (Lucas and Dawson 2014). These "true blooms" are a consequence of the coincidence of favorable environmental conditions (e.g. a pulse in prey abundance) with a jellyfish species whose traits enable it to take advantage of the conditions (Dawson and Hamner 2009). Zooxanthellate jellyfishes, however, are generally unlikely to bloom to the same degree as non-zooxanthellate jellyfishes, suggesting that the photosymbiosis limits their ability to respond to, or benefit from, pulses of prey (Dawson and Hamner 2009). Due to the correlated nature of character complexes-e.g. zooxanthellate scyphozoans are also predominantly monodisc strobilators whereas bloom forming, non-zooxanthellate scyphozoans are predominantly polydisc strobilators-it is challenging to identify the cause of this low blooming ability. Nonetheless, we believe that it would be valuable to formulate testable hypotheses to give a foundation for future research. Dawson and Hamner (2009) hypothesized several possible causes for the low blooming ability of zooxanthellate jellyfishes, as follows.

One hypothesis is that the mixotrophy of zooxanthellate jellyfishes implies trade-offs that physiologically limit their ability to take advantage of pulses of prey. For instance, several behavioral characteristics of zooxanthellate jellyfishes may limit their predation efficiency (see section 2.2.2.). The strobilation of many zooxanthellate jellyfishes is regulated by zooxanthellae (see section 2.3.2.) potentially decorrelating strobilation period from pulse of prey. Moreover, evidence from zooxanthellae-coral symbioses suggests that zooxanthellae can at times have negative effects on their hosts (Lesser et al. 2013, Hartmann et al. 2019). The existence of such trade-offs might also explain why many Cepheidae apparently tend to lose their symbionts at the medusa stage (Sugiura 1969, ESM 1). These trade-offs are, however, little known in zooxanthellate jellyfishes and more studies are needed to characterize them.

The other hypotheses relate to the ecological availability of resources and how zooxanthellate jellyfishes can use them. Dawson and Hamner (2009) proposed two mechanisms: (1) zooxanthellae may access a more stable resource stream as compared to prey abundances (Fig. 4a); (2) zooxanthellate jellyfishes may be able to switch from one resource to another (see section 2.3.3., Fig. 4b). In both cases, the generalism of 
511 zooxanthellate jellyfishes allow them to achieve a temporally smoother energetic income (as

512 opposed to non-zooxanthellate jellyfishes which, in this context, may be seen as specialists).

513 This would in turn result in smoother population dynamics and thus less abrupt population

514 increase, i.e. no unusual blooms. Along with these two hypotheses from Dawson and

515 Hamner (2009) we propose a third one: that some zooxanthellate jellyfishes might need

516 both autotrophy and heterotrophy (e.g. Kremer 2005; Welsh et al. 2009). Thus to bloom,

517 zooxanthellate jellyfishes would need both resources concomitantly in abundance. In the

518 context of the match-mismatch hypothesis developed for fisheries (see e. g. Cushing 1990)

519 the success of a given cohort is function of the timing between the spawning and a peak in

520 available prey. This can be transposed directly to non-zooxanthellate jellyfishes (Dawson and

521 Hamner 2009) where the strobilation corresponds to the spawning event. Zooxanthellate

522 jellyfishes, however, under the hypothesis that they need both autotrophic and

523 heterotrophic resources to bloom, would be dependent on appropriate timing of not one,

524 but two matching peaks of resources. Thus, because they rely on more diverse resources,

525 zooxanthellate jellyfishes would be more likely to encounter a mismatch than non-

526 zooxanthellate jellyfishes (Fig. 4c). Elevated possibility of mismatch for zooxanthellate

527 jellyfishes might also arise as a consequence of the additional control of zooxanthellae on

528 strobilation as compared to non-zooxanthellate jellyfishes (e.g. temperature cue for

529 strobilation and zooxanthellae presence might not always match, see section 2.3.2.) or

530 changing seasonality and phenology in the oceans (e. g. Mackas et al. 2012). This higher

531 chance of getting a mismatch would reduce zooxanthellate jellyfishes' likeliness to bloom. 

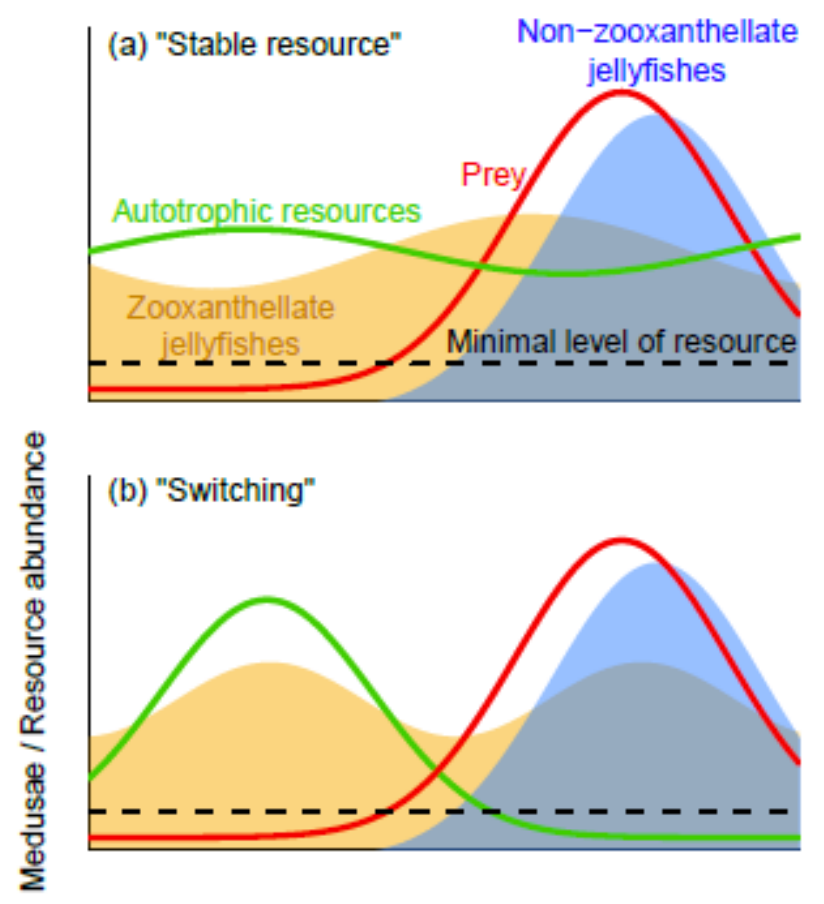

(c) "Double-dependency"

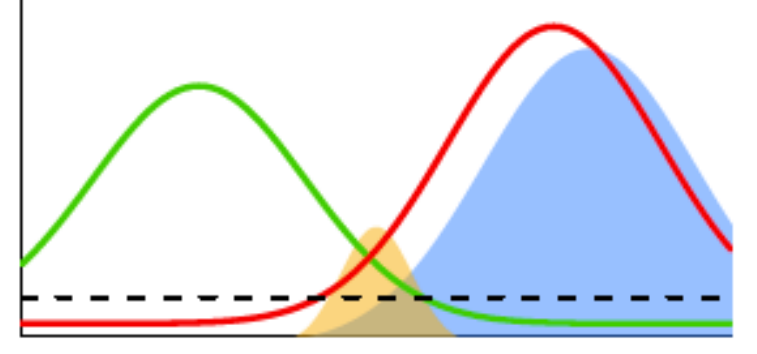

Time

532

533 Fig. 4 Three hypotheses on zooxanthellate jellyfishes' blooming ability as compared to nonzooxanthellate jellyfishes. Zooxanthellate jellyfishes (orange) are able to exploit both autotrophic resources (light, dissolved inorganic nutrients; green) and prey (red) whereas non-zooxanthellate jellyfishes (blue) can only exploit prey. Black dashed line indicates the minimum level of any resource to support a medusae population. (a) Hypothesis 1:

538 Zooxanthellae provide access to a more stable resource (the autotrophic resources), smoothing population dynamics. (b) Hypothesis 2: Zooxanthellae allow a diversification of resources, when one is insufficient, the other might compensate; again smoothing population dynamics. (c) Hypothesis 3: Zooxanthellate jellyfishes need both resource streams which exposes them to higher chances of mismatches reducing their likeliness to bloom. Schematics are illustrative only, and provided in simplified form to emphasize key

544 circumstances that may shape jellyfish population responses 
545 These different hypotheses might not be mutually exclusive. For instance, resource availability might vary across ecosystems or from year to year. The hypothesis in which zooxanthellate jellyfishes are able to switch resources (Fig. 4b) might represent a species that can tolerate a lot of variation in its nutrition (e.g. Phyllorhiza punctata - Bolton and Graham 2004). By opposition, the hypothesis in which zooxanthellate jellyfishes need both resources (Fig. 4c) would represent a species that cannot tolerate much variation in its nutrition. Thus, rather than being opposed these hypotheses might represent extremes of a continuum. It is also important to note that some species might not be within the scope of these hypotheses. For instance, Cephea (and possibly other Cepheidae; see ESM 1) loses its zooxanthellae at the medusa stage (Table 2), and might thus bloom (e.g. Cruz-Rivera and ElRegal 2015) as many other, non-zooxanthellate, jellyfishes. Similarly, Phyllorhiza punctata has invasive, non-zooxanthellate, populations that have been reported to bloom (Graham et al. 2003; Verity et al. 2011). Disentangling the conditions, species and environments in which a given hypothesis might best describe population dynamics and blooming ability is an important direction for future research on zooxanthellate jellyfishes.

\subsection{Reaction to Environmental Perturbations}

\subsubsection{Temperature driven bleaching}

As scleractinian corals, zooxanthellate jellyfish also can bleach (expel zooxanthellae) in response to a heat stress (Dawson et al. 2001; McGill and Pomoroy 2008; Newkirk et al. 2018; Klein et al. 2019). Few jellyfish bleaching event have been documented in the field; it is unclear whether such events are rarer, or simply less reported than in corals, but this would be an important question to resolve. The first report was of Mastigias papua from Clear Lake, a marine lake in Palau (Dawson et al. 2001).Subsequent experimental manipulations also elicited bleaching in conspecific polyps from nearby lakes at temperatures higher than $31.5^{\circ} \mathrm{C}$, providing a possible explanation for the subsequent Mastigias papua population collapse in the adjacent Ongeim'l Tketau marine lake during the extreme El Niño-La Niña oscillation of 1997-1999. Interestingly, the co-occurring nonzooxanthellate Aurelia sp. population did not experience such a collapse (Dawson et al. 2001). Another jellyfish bleaching event-of Cassiopea sp. medusae in the Red Sea, Saudi 
575

576

577

578

579

580

581

582

583

584

585

586

587

588

589

590

591

592

593

594

595

596

597

598

599

600

601

602

603

604

Arabia-occurred during a heat wave, after three consecutive days of atmospheric temperatures $>44{ }^{\circ} \mathrm{C}$. Mass mortality of the medusae occurred five to seven days after the bleaching event (Klein et al. 2019).

Recovery of a medusa population following a bleaching-induced collapse depends on replenishment from polyps and raises an intriguing scenario. As polyps do not rely on zooxanthellae to sustain their populations (section 3.3.1.) it can be expected that the requisite polyp populations will not have been depleted even if they bleached. However, because strobilation usually depends on zooxanthellae (section 3.3.2.), even a large population of bleached polyps may not be able to replenish the medusae population. In such cases, the recovery of the medusa population would depend on the reacquisition of zooxanthellae by the polyps (excepting the strobilation of aposymbiotic medusae, see Dawson et al. 2001).

However, as some zooxanthellate jellyfish species can sometimes realize their life-cycle without zooxanthellae (Table 2), bleaching may not always result in a population collapse. This is confirmed by observation of populations of apparently bleached, heterotrophic, mixed size-classes (from ca. 1 to $20 \mathrm{~cm}$ bell diameter) of Mastigias papua in Clear Lake, in Palau (Djeghri, Dawson, unpublished data). Moreover, remaining zooxanthellae in artificially bleached Cassiopea medusae are able to recolonize their host (Estes et al. 2003). Thus zooxanthellate jellyfishes might be able to survive a bleaching event either by the recovery of their zooxanthellae or by switching their nutrition towards predation.

\subsubsection{Eutrophication}

Some zooxanthellate jellyfish populations have been reported to increase after eutrophication events (García 1990; Arai 2001; Pérez-Ruzafa et al. 2002) or to have higher abundances in human-impacted sites, possibly due to higher nutrient concentrations (Stoner et al. 2011). This contrasts with what is seen in other photosymbiotic animals such as scleractinian corals (Fabricius et al. 2005; Lapointe et al. 2019) but is consistent with the tendency of some jellyfish species to be favored by eutrophication (Arai 2001; Purcell 2012). This apparent contradiction can be resolved if we consider that, generally speaking, zooxanthellate jellyfishes are less likely than benthic photosymbiotic organisms (such as 
605

606

607

608

609

610

611

612

613

614

615

616

617

618

619

620

621

622

623

624

625

626

627

628

629

630

631

632

633

634

corals) to suffer from the usual negative effects of eutrophication. For example, zooxanthellate medusae are not subject to competition with macroalgae. They can also compensate for turbidity by adjusting their depth either by swimming in planktonic species (Dawson and Hamner 2003), or by settling in shallower waters in the case of the benthic Cassiopea. Water turbidity could affect benthic polyps but, as discussed in previous sections, they do not rely much on their zooxanthellae and therefore, do not need much light. Moreover, scyphozoan polyps tend to be resistant to the conditions associated with eutrophication (Purcell 2012; see also Klein et al. 2017). Eutrophic ecosystems could even present advantages for zooxanthellate jellyfishes as they are characterized by a greater availability of nutrients, which can promote the growth of zooxanthellae in zooxanthellate jellyfishes (see e.g. Freeman et al. 2017) and may, in normal circumstances, be limiting (see section 3.2.).

\subsection{Impacts on Ecosystems}

In some ecosystems, zooxanthellate jellyfish populations reach densities up to tens or hundreds of medusae per $1000 \mathrm{~m}^{-3}$ (e.g. Hamner et al. 1982; García 1990; Pérez-Ruzafa et al. 2002; Gueroun et al. 2014; Cimino et al. 2018). Such densities likely strongly impact these ecosystems in various ways. Some of these impacts can be very similar to those induced by non-zooxanthellate jellyfishes such as high predation pressure on zooplankton (e.g. García and Durbin 1993). However, due to their particular traits, zooxanthellate jellyfishes could impact ecosystems in ways that differ from what is known from their non-zooxanthellate counterparts.

\subsubsection{Primary productivity}

Individual zooxanthellate jellyfishes can reach primary productivity levels comparable to those of scleractinian corals (Kremer et al. 1990). Therefore, when abundant, zooxanthellate jellyfishes can represent an important fraction of the primary productivity of the ecosystem they inhabit. For instance, Mastigias papua medusae can contribute $16 \%$ of the primary productivity in the marine lake Ongeim I'Tketau in Palau (McCloskey et al. 1994). However, this high contribution may approach the upper bound of primary production contributions 
by zooxanthellate jellyfishes: the population density of Mastigias papua medusae in Ongeim I'Tketau can be very high (on average ca. 1000 medusae per $1000 \mathrm{~m}^{-3}$; Hamner et al. 1982; Cimino et al. 2018). In other ecosystems, even when zooxanthellate jellyfishes are numerous they rarely attain densities as high (maximum densities of ca. 100 medusae per $1000 \mathrm{~m}^{-3} \mathrm{e}$. g. García 1990; Pérez-Ruzafa et al. 2002). Moreover, whereas jellyfish productivity can be directed towards higher trophic levels (Hays et al. 2018), when their populations attain high densities, most of their production may be instead directed towards microbial respiration (Condon et al. 2011) or exported (e. g. Billet et al. 2006). Hence, it is unlikely that zooxanthellate jellyfishes would contribute as much as scleractinian corals to productivity in their ecosystems.

\subsubsection{Nutrient cycling}

Zooxanthellate jellyfishes can affect nutrient cycling in the ecosystems they inhabit. One example already mentioned is the pumping action of the benthic medusae Cassiopea spp. which releases nutrient-rich pore water for its zooxanthellae but also for the pelagic community (Jantzen et al. 2010). However, this positive impact of zooxanthellate jellyfishes on pelagic nutrient fluxes should probably be considered as an exception. Pitt et al. (2009) suggested that the recycling and uptake of nutrients by zooxanthellate jellyfishes implies that they act more as sinks for nutrients than as sources (unlike non-zooxanthellate jellyfishes). This, in turn, can impact planktonic communities.

\subsubsection{Planktonic communities}

Pitt et al. (2009) suggested that if zooxanthellate jellyfishes act as sinks for dissolved inorganic nutrients, then this implies fewer nutrients are available for phytoplankton growth. Moreover, some characteristics of zooxanthellate jellyfishes might reduce their predation efficiency (Dawson and Hamner 2009; see section 2.2.2.). Thus Pitt et al. (2009) concluded that the presence of zooxanthellate jellyfish would reduce phytoplankton population densities by two means. First, a bottom-up effect where the zooxanthellate jellyfishes makes nutrients unavailable to phytoplankton. Second, a top-down effect where predation on zooplankton by zooxanthellate jellyfishes is relatively low (as compared with non- 
zooxanthellate jellyfishes); zooplankton populations would thus be larger and predation pressure on phytoplankton would increase. This hypothesis has been successfully tested in mesocosm experiments (West et al. 2009).

It is however important to stress that the impacts discussed here concern mainly quite specific ecosystems (i.e. lagoons) that are characterized by important densities of jellyfishes and that are more or less enclosed. In more open coastal areas, or in the open ocean, only little is known of zooxanthellate jellyfishes' population fluctuations and potential impacts on community dynamics and ecosystem functioning.

\section{Summary and Knowledge Gaps}

Zooxanthellate jellyfishes can be found in lineages across the medusozoan phylogeny (Fig. 1). Most of the zooxanthellate jellyfish species are isolated in mostly non-zooxanthellate clades with the notable exception of Kolpophorae (Rhizostomeae: Scyphozoa). Zooxanthellate jellyfishes' reliance on their symbionts can vary across species, populations and ontogeny (Fig. 3, Table 2). Three key traits can be identified: (1) As holobionts, the medusae are generally mixotrophic, although many variations can be observed; (2) in contrast, the polyps, although being able to host zooxanthellae, do not rely much on zooxanthellae for survival, growth and budding; and (3) zooxanthellae play a key role during strobilation. Due to these traits, zooxanthellate jellyfishes may have different ecologies when compared to non-zooxanthellate jellyfishes (e.g. different blooming ability, Fig. 4) or to other photosymbiotic cnidarians such as scleractinian corals (e.g. reaction to eutrophication).

However, there are still substantial gaps in our current understanding of zooxanthellate jellyfish ecology. Hydrozoan and cubozoan zooxanthellate jellyfishes are, in most cases, only described to occur, with no in depth study of their ecology. Basic information on the lifecycle and nutrition is still lacking for most species. Most of our knowledge comes from large, coastal, scyphozoan species which may not be representative of other groups or of other environments such as the open ocean. The best studied genus is Cassiopea since it has been used as a model organism for the study of cnidarian-zooxanthellae symbiosis (see recent 
695

696

697

698

699

700

701

702

703

704

705

706

707

708

709

710

711

712

713

714

715

716

717

718

719

720

721

review; Ohdera et al. 2018). However, due to the benthic life-style of its medusae, this genus may not be the best model for understanding pelagic zooxanthellate jellyfish ecology. Our understanding of zooxanthellate jellyfish diversity and ecology would benefit from more systematic assessment-e. g. using microscope study or molecular methods-of the presence of zooxanthellae in a wide range of medusozoans. Albeit generally mixotrophic, zooxanthellate medusae display a great variability in their nutrition, which also needs to be characterized better given its implications for the ecologies of these species. Traditional measures of predation, photosynthesis, respiration and excretion (e. g. Kremer 2005) would be beneficial though time consuming. More recent methods, involving trophic markers such as stable isotopes or fatty acids have been applied successfully to other photosymbiotic animals such as corals (see e. g. Ferrier-Pagès and Leal 2018; Mies et al. 2018) and would usefully be applied to zooxanthellate jellyfishes (e. g. Mortillaro et al. 2009; Freeman et al. 2017; Zeman et al. 2018). The last, but possibly major caveat with the study of zooxanthellate jellyfishes may be due to the way we divide our scientific fields.

Zooxanthellate jellyfishes are somewhat caught between jellyfish focused researchers and coral focused researchers. To gain insight of zooxanthellate jellyfishes' biology and ecology, we need to bring together ideas from these two communities.

\section{Compliance with ethical standards:}

Conflict of interest All authors declare that they have no conflict of interest.

Ethical approval This article does not contain any work involving animals performed by any of the authors

\section{References}

Arai MN (1997) A functional biology of Scyphozoa. Chapman \& Hall, London Arai MN (2001) Pelagic coelenterates and eutrophication: a review. Hydrobiologia 451:69-87 
Astorga D, Ruiz J, Prieto L (2012) Ecological aspects of early life stages of Cotylorhiza tuberculata (Scyphozoa: Rhizostomae) affecting its pelagic population success. Hydrobiologia 690:141-155

Banaszak AT, Iglesias-Prieto R, Trench RK (1993) Scrippsiella velellae sp. nov.

(Peridiniales) and Gloeodinium viscum sp. nov. (Phytodiniales), Dinoflagellate symbionts of two hydrozoans (Cnidaria). J Phycol 29:517-528

Bayha KM, Dawson MN, Collins AG, Barbeitos MS, Haddock SHD (2010) Evolutionary relationships among scyphozoan jellyfish families based on complete taxon sampling and phylogenetic analyses of $18 \mathrm{~S}$ and $28 \mathrm{~S}$ ribosomal DNA. Integr Comp Biol 50:436-455 Bayha KM, Graham WM (2014) Nonindigenous marine jellyfish: invasiveness, invasibility, and impacts. In: Pitt K, Lucas C (eds) Jellyfish blooms. Springer, Dordrecht, pp 45-77 Bezio N, Costello JH, Perry E, Colin SP (2018) Effect of capture surface morphology on feeding success of scyphomedusae: a comparative study. Mar Ecol Prog Ser 596:83-93 Bieri R (1977) The ecological significance of seasonal occurrence and growth rate of Velella (Hydrozoa). Publ Seto Mar Biol Lab 24:63-76

Billett DSM, Bett BJ, Jacobs CL, Rouse IP, Wigham BD (2006) Mass deposition of jellyfish in the deep Arabian Sea. Limnol Oceanogr 51:2077-2083

Blanquet RS, Phelan MA (1987) An unusual blue mesogleal protein from the mangrove jellyfish Cassiopea xamachana. Mar Biol 94:423-430

Blanquet RS, Riordan GP (1981) An ultrastructural study of the subumbrellar musculature and desmesomal complexes of Cassiopea xamachana (Cnidaria: Scyphozoa). Trans Am Microsc Soc 100:109-119

Boero F, Brotz L, Gibbons MJ, Piraino S, Zampardi S (2016) Impacts and effects of ocean warming on jellyfish. In: Laffoley D, Baxter JM (eds) Explaining ocean warming: Causes, scale, effects and consequences. IUCN, Gland, pp 213-237

Bolton TF, Graham WM (2004) Morphological variation among populations of an invasive jellyfish. Mar Ecol Prog Ser 278:125-139 
Bouillon J (1984) Hydroméduses de la mer de Bismarck (Papouasie Nouvelle-Guinée. Partie IV : Leptomedusae (Hydrozoa-Cnidaria). Indo-Malayan Zool 1 :25-112

Bouillon J, Seghers G, Boero F (1988) Notes additionnelles sur les méduses de Papouasie Nouvelle-Guinée (Hydrozoa, Cnidaria) III. Indo-Malayan Zool 5:225-253

Bouillon J, Gravili C, Pagès F, Gili J-M, Boero F (2006) An introduction to Hydrozoa. Publications Scientifiques du Muséum, Paris

Brinckmann-Voss A, Arai MN (1998) Further notes on Leptolida (Hydrozoa: Cnidaria) from Canadian Pacific waters. Zool Verh 323:37-68

Brooks WK (1903) On a new genus of hydroid jelly-fishes. Proc Am Phil Soc 42:11-14

Calder DR (1990) Shallow-water hydroids of Bermuda: the Thecatae, exclusive of Plumularioidea. Royal Ontario Museum Publications in Life Sciences 154

Carrette T, Straehler-Pohl I, Seymour J (2014) Early life history of Alatina cf. moseri populations from Australia and Hawaii with implications for taxonomy (Cubozoa: Carybdeida, Alatinidae). PLoS ONE 9:e84377 Cates N (1975) Productivity and organic consumption in Cassiopea and Condylactus. J Exp Mar Biol Ecol 18:55-59

Cates N, McLaughlin JJA (1976) Differences of ammonia metabolism in symbiotic and aposymbiotic Condylactus and Cassiopea spp. J Exp Mar Biol Ecol 21:1-5

Cimino MA, Patris S, Ucharm G, Bell LJ, Terrill E (2018) Jellyfish distribution and abundance in relation to the physical habitat of Jellyfish Lake, Palau. J Trop Ecol 34:17-31 Colley NJ, Trench RK (1985) Cellular events in the reestablishment of a symbiosis between a marine dinoflagellate and a coelenterate. Cell Tissue Res 239:93-103 Condon RH, Steinberg DK, del Giorgio PA, Bouvier TC, Bronk DA, Graham WM, Ducklow HW (2011) Jellyfish blooms result in a major microbial respiratory sink of carbon in marine systems. Proc Nat Acad Sci USA 108:10225-10230 Condon RH, Duarte CM, Pitt KA, Robinson KL, Lucas CH, Sutherland KR, Mianzan HW, Bogeberg M, Purcell JE, Decker MB, Uye S-I, Madin LP, Brodeur RD, Haddock SHD, Malej 
A, Parry GD, Eriksen E, Quiñones J, Acha M, Harvey M, Arthur JM, Graham WM (2013) Recurrent jellyfish blooms are a consequence of global oscillations. Proc Nat Acad Sci USA 110:1000-1005

Costello JH, Kremer PM (1989) Circadian rhythmicity in the location of zooxanthellae of the scyphomedusa Linuche unguiculata. Mar Ecol Prog Ser 57:279-286

Cruz-Rivera E, El-Regal MA (2015) A bloom of an edible scyphozoan jellyfish in the Red Sea. Mar Biodivers 46:515-519

Cushing DH (1990) Plankton production and year-class strength in fish populations: an update of the match/mismatch hypothesis. Adv Mar Biol 26:249-293

Daly M, Brugler MR, Cartwright P, Collins AG, Dawson MN, Fautin DG, France SC, McFadden CS, Opresko DM, Rodriguez E, Romano SL, Stake JL (2007) The phylum

Davy SK, Allemand D, Weis VM (2012) Cell biology of Cnidarian-Dinoflagellate symbiosis.

Dawson MN, Hamner WM (2003) Geographic variation and behavioral evolution in marine plankton: the case of Mastigias (Scyphozoa, Rhizostomeae). Mar Biol 143:11611174

Dawson MN, Hamner WM (2009) A character-based analysis of the evolution of jellyfish blooms: adaptation and exaptation. Hydrobiologia 616:193-215 Hydrobiologia 451:131-144 

Drew EA (1972) The biology and physiology of alga-invertebrate symbioses. I. Carbon fixation in Cassiopea sp. at Aldabra Atoll. J Exp Mar Biol Ecol 9:65-69

Duarte CM, Pitt KA, Lucas CH, Purcell JE, Uye S-I, Robinson K, Brotz L, Decker MB, Sutherland KR, Malej A, Madin L, Mianzan H, Gili J-M, Fuentes V, Atienza D, Pagés F, Breitburg D, Malek J, Graham WM, Condon RH (2012) Is global ocean sprawl a cause of jellyfish blooms? Front Ecol Environ 11:91-97

Estes AM, Kempf SC, Henry RP (2003) Localization and quantification of carbonic anhydrase activity in the symbiotic scyphozoan Cassiopea xamachana. Biol Bull 204:278289

Fabricius KE (2005) Effects of terrestrial runoff on the ecology of corals and coral reefs: review and synthesis. Mar Pollut Bull 50:125-146

Ferrier-Pagès C, Leal MC (2018) Stable isotopes as tracers of trophic interactions in marine mutualistic symbioses. Ecol Evol 9:723-740

Fitt WK (1984) The role of chemosensory behavior of Symbiodinium microadriaticum, intermediate hosts, and host behavior in the infection of coelenterates and molluscs with zooxanthellae. Mar Biol 81:9-17

Fitt WK, Costley K (1998) The role of temperature in survival of the polyp stage of the tropical rhizostome jellyfish Cassiopea xamachana. J Exp Mar Biol Ecol 222:79-91

Fitt WK, Cook CB (2001) The effects of feeding or addition of dissolved inorganic nutrients in maintaining the symbiosis between dinoflagellates and a tropical marine cnidarian. Mar Biol 139:507-517

Fleck J, Fitt WK (1999) Degrading mangrove leaves of Rhizophora mangle Linne provide a natural cue for settlement and metamorphosis of the upside down jellyfish Cassiopea xamachana Bigelow. J Exp Mar Biol Ecol 234:83-94

Freeman CJ, Stoner EW, Easson CG, Matterson KO, Baker DM (2016) Symbiont carbon and nitrogen assimilation in the Cassiopea-Symbiodinium mutualism. Mar Ecol Prog Ser 544:281-286 
Freeman CJ, Stoner EW, Easson CG, Matterson KO, Baker DM (2017) Variation in $\delta^{13} \mathrm{C}$ and $\delta^{15} \mathrm{~N}$ values suggests a coupling of host and symbiont metabolism in the Symbiodinium-Cassiopea mutualism. Mar Ecol Prog Ser 571:245-251

Freudenthal HD (1962) Symbiodinium gen. nov. and Symbiodinium microadriaticum sp. nov., a zooxanthella: taxonomy, life cycle, and morphology. J Protozool 9:45-52

Fuentes V, Straehler-Pohl I, Atienza D, Franco I, Tilves U, Gentile M, Acevedo M, Oleriaga A, Gili J-M (2011) Life cycle of the jellyfish Rhizostoma pulmo (Scyphozoa: Rhizostomeae) and its distribution, seasonality and inter-annual variability along the Catalan coast and the Mar Menor (Spain, NW Mediterranean). Mar Biol 158:2247-2266

Furla P, Richier S, Allemand D (2011) Physiological adaptation to symbiosis in cnidarians. In: Dubinsky Z, Stambler N (eds) Coral reefs: an ecosystem in transition. Springer, Dordrecht, pp 187-195

Galea HR, Ferry R (2015) Notes on some hydroids (Cnidaria) from Martinique, with descriptions of five new species. Rev suisse Zool 122:213-246

García JR (1990) Population dynamics and production of Phyllorhiza punctata (Cnidaria: Scyphozoa) in Laguna Joyuda, Puerto Rico. Mar Ecol Prog Ser 64:243-251

García JR, Durbin E (1993) Zooplanktivorous predation by large scyphomedusae Phyllorhiza punctata (Cnidaria: Scyphozoa) in Laguna Joyuda. J Exp Mar Biol Ecol 173:7193

Graham WM, Martin DL, Felder DL, Asper VL, Perry HM (2003) Ecological and economic implications of a tropical jellyfish invader in the Gulf of Mexico. Biol Invasions 5:53-69 Gershwin L, Davie PJF (2013) A remarkable new jellyfish (Cnidaria: Scyphozoa) from coastal Australia, representing a new suborder within the Rhizostomeae. Mem QueensI Mus 56:625-630

Gómez Daglio L, Dawson MN (2017) Species richness of jellyfishes (Scyphozoa: Discomedusae) in the Tropical Eastern Pacific: missed taxa, molecules, and morphology match in a biodiversity hotspot. Invertebr Syst 31:635-663 

Gueroun SKM, Kéfi-Daly Yahia O, Deidun A, Fuentes V, Piraino S, Daly Yahia MN (2014) First record and potential trophic impact of Phyllorhiza punctata (Cnidaria: Scyphozoa) along the north Tunisian coast (South Western Mediterranean Sea). Ital J Zool 8:95-100 Haddad MA, Nogueira Júnior M (2006) Reappearance and seasonality of Phyllorhiza punctata von Lendenfeld (Cnidaria, Scyphozoa, Rhizostomeae) medusae in southern Brazil. Rev Bras Zool 23:824-831

Hamner WM, Hauri IR (1981) Long-distance horizontal migrations of zooplankton (Scyphomedusae: Mastigias). Limnol Oceanogr 26:414-423 Hamner WM, Gilmer RW, Hamner PP (1982) The physical, chemical, and biological characteristics of a stratified, saline, sulfide lake in Palau. Limnol Oceanogr 27:896-909 Hartmann AC, Marhaver KL, Klueter A, Lovci MT, Closek CJ, Diaz E, Chamberland VF, Archer FI, Deheyn DD, Vermeij MJA, Medina M (2019) Acquisition of obligate symbionts during the larval stage is not beneficial for a coral host. Mol Ecol 28:141-155

Hays GC, Doyle TK, Houghton JDR (2018) A paradigm shift in the trophic importance of jellyfish? Trends Ecol Evol 33:874-884

Heins A, Glatzel T, Holst S (2015) Revised descriptions of the nematocysts and the asexual reproduction modes of the scyphozoan jellyfish Cassiopea andromeda (Forskål, 1775). Zoomorphology 134:351-366

Helm RR (2018) Evolution and development of scyphozoan jellyfish. Biol Rev 93:12281250

Hofmann DK, Kremer BP (1981) Carbon metabolism and strobilation in Cassiopea andromedea (Cnidaria: Scyphozoa): Significance of endosymbiotic Dinoflagellates. Mar Biol 65:25-33

Hofmann DK, Neumann R, Henne K (1978) Strobilation budding and initiation of scyphistome morphogenesis in the Rhizostome Cassiopea andromeda (Cnidaria: Scyphozoa). Mar Biol 47:161-176 
Hofmann DK, Fitt WK, Fleck J (1996) Checkpoints in the life-cycle of Cassiopea spp.: control of metagenesis and metamorphosis in a tropical jellyfish. Int J Dev Biol 40:331338

Holland BS, Dawson MN, Crow GL, Hofmann DK (2004) Global phylogeography of Cassiopea (Scyphozoa: Rhizostomeae): molecular evidence for cryptic species and multiple invasions of the Hawaiian Islands. Mar Biol 145:1119-1128

Jantzen C, Wild C, Rasheed M, El-Zibdah M, Richter C (2010) Enhanced pore-water nutrient fluxes by the upside-down jellyfish Cassiopea sp. in a Red Sea coral reef. Mar Ecol Prog Ser 411:117-125

Kayal E, Bentlage B, Cartwright P, Yanagihara AA, Lindsay DJ, Hopcroft RR, Collins AG (2015) Phylogenetic analysis of higher-level relationships within Hydroidolina (Cnidaria: Hydrozoa) using mitochondrial genome data and insight into their mitochondrial transcription. PeerJ 3:e1403

Kayal E, Bentlage B, Pankey MS, Ohdera AH, Medina M, Plachetzki DC, Collins AG, Ryan JF (2018) Phylogenomics provides a robust topology of the major cnidarian lineages and insights on the origins of key organismal traits. BMC Evol Biol 18:68

Kikinger R (1992) Cotylorhiza tuberculata (Cnidaria: Scyphozoa) - Life history of a stationary population. Mar Ecol 13:333-362

Klein SG, Pitt KA, Nitschke MR, Goyen S, Welsh DT, Suggett DJ, Carroll AR (2017) Symbiodinium mitigate the combined effects of hypoxia and acidification on a noncalcifying cnidarian. Glob Change Biol 23:3690-3703

Klein SG, Pitt KA, Lucas CH, Hung S-H, Schmidt-Roach S, Aranda M, Duarte CM (2019) Night-time temperature reprieves enhances the thermal tolerance of a symbiotic cnidarian. Front Mar Sci 6:453

Kramp PL (1961) Synopsis of the medusae of the world. J Mar Biol Assoc UK 40:1-469

Kremer P (2005) Ingestion and elemental budgets for Linuche unguiculata, a scyphomedusa with zooxanthellae. J Mar Biol Assoc UK 85:613-625 
Kremer P, Costello J, Kremer J, Canino M (1990) Significance of photosynthetic endosymbionts to the carbon budget of the schyphomedusa Linuche unguiculata. Limnol Oceanogr 35:609-624

LaJeunesse TC (2001) Investigating the biodiversity, ecology, and phylogeny of endosymbiotic dinoflagellates in the genus Symbiodinium using the ITS region: in search of a "species" level marker. J Phycol 37:866-880

LaJeunesse TC, Parkinson JE, Gabrielson PW, Jeong HJ, Reimer JD, Voolstra CR, Santos SR (2018) Systematic revision of Symbiodiniaceae highlights the antiquity and diversity of coral endosymbionts. Curr Biol 28:2570-2580

Lampert KP (2016) Cassiopea and its zooxanthellae. In: Goffredo S, Dubinsky Z (eds) The cnidaria, past, present and future. Springer, Cham, pp 415-423

Lampert KP, Bürger P, Striewski S, Tollrian R (2012) Lack of association between color morphs of the jellyfish Cassiopea andromeda and zooxanthella clade. Mar Ecol 33:364369

Lapointe BE, Brewton RA, Herren LW, Porter JW, Hu C (2019) Nitrogen enrichment, altered stoichiometry, and coral reef decline at Looe Key, Florida Keys, USA: a 3-decade study. Mar Biol 166:108

Larson RJ (1980) The medusae of Velella velella (Linnaeus, 1758) (Hydrozoa, Chondrophorae). J Plankton Res 2:183-186

Larson RJ (1992) Riding Langmuir circulations and swimming in circle: a novel form of clustering behavior by the scyphomedusa Linuche unguiculata. Mar Biol 112:229-235 Larson RJ (1997) Feeding behaviour of Caribbean scyphomedusae: Cassiopea frondosa (Pallas) and Cassiopea xamachana Bigelow. Stud Nat Hist Caribbean Region 73:43-54 Lesser MP, Stat M, Gates RD (2013) The endosymbiotic dinoflagellates (Symbiodinium sp.) of corals are parasites and mutualists. Coral Reefs 32:603-611

Lewis JB (1991) The ampullae and medusae of the calcareous hydrozoan Millepora complanata. Hydrobiologia 216/217:165-169 
Lewis JB (2006) Biology and ecology of the hydrocoral Millepora on coral reefs. Adv Mar Biol 50:1-55

Lopes AR, Baptista M, Rosa IC, Dionísio G, Gomes-Pereira J, Paula JR, Figueiredo C, Bandarra N, Calado R, Rosa R (2016) "Gone with the wind": fatty acid biomarkers and chemotaxonomy of stranded pleustonic hydrozoans (Velella velella and Physalia physalis). Biochem Syst Ecol 66:297-306

Lucas CH, Dawson MN (2014) What are jellyfish and Thaliaceans and why do they bloom? In: Pitt KA, Lucas CH (eds) Jellyfish blooms. Springer, Dordrecht, pp 9-44

Lucas CH, Graham WM, Widmer C (2012) Jellyfish life histories: role of polyps in forming and maintaining scyphomedusa populations. Adv Mar Biol 63:133-196 Ludwig F-D (1969) Die Zooxanthellan bei Cassiopea andromeda Eschscholtz 1829 (PolypStadium) und ihre Bedeutung für die Strobilation. Zoologische Jahrbücher. Abt Anat Ontog Tiere 86:238-277

Mackas DL, Greve W, Edwards M, Chiba S, Tadokoro K, Eloire D, Mazzochi MG, Batten S, Richardson AJ, Johnson C, Head E, Conversi A, Peluso T (2012) Changing zooplankton seasonality in a changing ocean: Comparing time series of zooplankton phenology. Prog Oceanogr 97:31-62

Mangan J (1909) The entry of zooxanthellae into the ovum of Millepora, and some particulars concerning the medusae. J Cell Sci 53:697-710

Maronna MM, Miranda TP, Peña Cantero ÁL, Barbeitos MS, Marques AC (2016) Towards a phylogenetic classification of Leptothecata (Cnidaria, Hydrozoa). Sci Rep 6:18075

Marques AC, Peña Cantero AL, Vervoort W (2000) Mediterranean species of Eudendrium Ehrenberg, 1834 (Hydrozoa, Anthomedusae, Eudendriidae) with the description of a new species. J Zool Soc London 252:197-213

Martin LE, Dawson MN, Bell L, Colin PL (2006) Marine lake ecosystem dynamics illustrate ENSO variation in the tropical western Pacific. Biol Lett 2:144-147

McCloskey LR, Muscatine L, Wilkerson FP (1994) Daily photosynthesis, respiration, and carbon budgets in a tropical marine jellyfish (Mastigias sp.). Mar Biol 119:13-22 

McGill CJ, Pomoroy CM (2008) Effects of bleaching and nutrient supplementation on wet weight in the jellyfish Cassiopea xamachana (Bigelow) (Cnidaria: Scyphozoa). Mar Freshw Behav Physiol 41:179-189

Medel MD, Vervoort W (1995) Plumularian hydroids (Cnidaria: Hydrozoa) from the Strait of Gibraltar and nearby areas. Zool Verh 300:1-72

Mellas RE, Mcllroy SE, Fitt WK, Coffroth MA (2014) Variation in symbiont uptake in the early ontogeny of the upside-down jellyfish, Cassiopea spp. J Exp Mar Biol Ecol 459:3844

Mergner H, Svoboda A (1977) Productivity and seasonal changes in selected reef areas in the Gulf of Aquaba (Red Sea). Helgol Meeresunters 30:383-399 Montgomery MK, Kremer PM (1995) Transmission of symbiotic dinoflagellates through the sexual cycle of the host scyphozoan Linuche unguiculata. Mar Biol 124:147-155 Mies M, Güth AZ, Tenório AA, Banha TNS, Waters LG, Polito PS, Taniguchi S, Bícego MC, Sumida PYG (2018) In situ shifts of predominance between autotrophic and heterotrophic feeding in the reef-building coral Mussismilia hispida: an approach using fatty acid trophic markers. Coral Reefs 37:677-689

Morandini AC, Stampar SN, Maronna MM, Silveira FL da (2017) All non-indigenous species were introduced recently? The case study of Cassiopea (Cnidaria: Scyphozoa) in Brazilian waters. J Mar Biol Assoc UK 97:321-328

Mortillaro JM, Pitt KA, Lee SY, Meziane T (2009) Light intensity influences the production and translocation of fatty acids by zooxanthellae in the jellyfish Cassiopea sp. J Exp Mar Biol Ecol 378:22-30

Moura CJ, Lessios H, Cortés J, Nizinski MS, Reed J, Santos RS, Collins AG (2018) Hundreds of genetic barcodes of the species-rich hydroid superfamily Plumularioidea (Cnidaria, Medusozoa) provide a guide toward more reliable taxonomy. Sci Rep 8:17986 Muscatine L (1974) Endosymbiosis of cnidarians and algae. In: Muscattine L, Lenhoff HM (eds) Coelenterate biology: reviews and new perspectives. Academic Press, New York, pp 359-395 
Muscatine L, Marian RE (1982) Dissolved inorganic nitrogen flux in symbiotic and nonsymbiotic medusae. Limnol Oceanogr 27:910-917

$$
\text { Muscatine L, Wilkerson FP, McCloskey LR (1986) Regulation of population density of }
$$
symbiotic algae in a tropical marine jellyfish (Mastigias sp.). Mar Ecol Prog Ser 32:279290

Nawrocki AM, Schuchert P, Cartwright P (2010) Phylogenetics and the evolution of Capitata (Cnidaria: Hydrozoa), and the systematics of Corynidae. Zool Scr 39:290-304

Newkirk CR, Frazer TK, Martindale MQ (2018) Acquisition and proliferation of algal symbionts in bleached polyps of the upside-down jellyfish, Cassiopea xamachana. J Expl Mar Biol Ecol 508:44-51

Ohdera AH, Abrams MJ, Ames CL, Baker DM, Suescún-Bolivar LP, Collins AG, Freeman CJ, Gamero-Mora E, Goulet TL, Hofmann DK, Jaimes-Becerra A, Long PF, Marques AC, Miller LA, Mydlarz LD, Morandini AC, Newkirk CR, Putri SP, Samson JE, Stampar SN, Steinworth B, Templeman M, Thomé PE, Vlok M, Woodley CM, Wong JCY, Martindale MQ, Fitt WK, Medina M (2018) Upside-down but headed in the right direction: review of the highly versatile Cassiopea xamachana system. Front Ecol Evol 6:35

Ortiz-Corp's E, Cutress CE, Cutress BM (1987) Life history of the Coronate scyphozoan Linuche unguiculata (Swartz, 1788). Caribb J Sci 23:432-443

Pagliara P, Bouillon J, Boero F (2000) Photosynthetic planulae and planktonic hydroids: contrasting strategies of propagule survival. Sci Mar 64:173-178

Peach MB, Pitt KA (2005) Morphology of the nematocysts of the medusae of two scyphozoans, Catostylus mosaicus and Phyllorhiza punctata (Rhizostomeae): implication for capture of prey. Invertebr Biol 124:98-108

Pérez-Ruzafa A, Gilabert J, Gutiérrez JM, Fernández Al, Marcos C, Sabah S (2002) Evidence of a planktonic food web response to changes in nutrient input dynamics in the Mar Menor coastal lagoon, Spain. Hydrobiologia 475/476:359-369

Pitt KA, Koop K, Rissik D, Kingsford MJ (2004) The ecology of scyphozoan jellyfish in Lake Illawara. Wetlands (Australia) 21:115-123 
Pitt KA, Koop K, Rissik D (2005) Contrasting contributions to inorganic nutrient recycling by the co-occuring jellyfishes, Catostylus mosaicus and Phyllorhiza punctata (Scyphozoa, Rhizostomeae). J Exp Mar Biol Ecol 315:71-86

Pitt KA, Welsh DT, Condon RH (2009) Influence of jellyfish blooms on carbon, nitrogen and phosphorus cycling and plankton production. Hydrobiologia 616:133-149

Prieto L, Astorga D, Navarro G, Ruiz J (2010) Environmental control of phase transition and polyp survival of a massive-outbreaker Jellyfish. PLoS ONE 5:e13793

Probert I, Siano R, Poirier C, Decelle J, Biard T, Tuji A, Suzuki N, Not F (2014) Brandtodinium gen. nov. and B. nutricula comb. nov. (Dinophyceae) a dinoflagellate commonly found in symbiosis with polycistine radiolarians. J Phycol 50:388-399

Purcell JE (2012) Jellyfish and ctenophore blooms coincide with human proliferations and environmental perturbations. Ann Rev Mar Sci 4:209-235

Purcell JE, Clarkin E, Doyle TK (2012a) Foods of Velella velella (Cnidaria: Hydrozoa) in algal rafts and its distribution in Irish seas. Hydrobiologia 690:47-55

Purcell JE, Atienza D, Fuentes V, Olariaga A, Tilves U, Colahan C, Gili J-M (2012b) Temperature effects on asexual reproduction rates of scyphozoan species from the northwest Mediterranean Sea. Hydrobiologia 690:169-180

Purcell JE, Milisenda G, Rizzo A, Carrion SA, Zampardi S, Airoldi S, Zagami G, Guglielmo L, Boero F, Doyle TK, Piraino S (2015) Digestion and predation rates of zooplankton by the pleustonic hydrozoan Velella velella and widespread blooms in 2013 and 2014. J Plankton Res 37:1056-1067

Rahat M, Adar O (1980) Effect of symbiotic zooxanthellae and temperature on budding and strobilation in Cassiopea andromeda (Eschscholz). Biol Bull+ 159:394-401

Rippingale RJ, Kelly SJ (1995) Reproduction and survival of Phyllorhiza punctata (Cnidaria: Rhizostomeae) in a seasonally fluctuating salinity regime in Western Australia. Mar Freshw Res 46:1145-1151 
Ruiz J, Prieto L, Astorga D (2012) A model for temperature control of jellyfish (Cotylorhiza tuberculata) outbreaks: a causal analysis in a Mediterranean coastal lagoon. Ecol Modell 233:59-69

Santhanakrishnan A, Dollinger M, Hamlet CL, Colin SP, Miller LA (2012) Flow structure and transport characteristics of feeding and exchange currents generated by upsidedown Cassiopea jellyfish. J Exp Biol 215:2369-2381 phylogeny of symbiotic dinoflagellates inferred from partial chloroplast large subunit (23S)-rDNA sequences. Mol Phylogenetics Evol 23:97-111

Schiariti A, Morandini AC, Jarms G, von Glehn Paes R, Franke S, Mianzan H (2014) Asexual reproduction strategies and blooming potential in Scyphozoa. Mar Ecol Prog Ser 510:241-253

Silveira FL da, Morandini AC (1997) Nausithoe aurea n. sp. (Scyphozoa, Coronatae: Nausithoidae), a species with two pathways of reproduction after strobilation: sexual and asexual. Contrib Zool 66:235-246 Silveira FL da, Morandini AC (1998) Asexual reproduction in Linuche unguiculata (Swartz, 1788) (Scyphzoa: Coronatae) by planuloid formation through strobilation and segmentation. Proc Biol Soc Washington 111:781-794

Simpson GG (1953) The major features of evolution. Columbia University Press, New York

Soong K, Cho LC (1998) Synchronized release of medusae from three species of hydrozoan fire corals. Coral Reefs 17:145-154 Souza LM de, lacomini M, Gorin PAJ, Sari RS, Haddad MA, Sassaki GL (2007) Glyco- and sphingophoslipids from the medusa Phyllorhiza punctata: NMR and ESI-MS/MS fingerprints. Chem Phys Lipids 145:85-96

Straehler-Pohl I, Jarms G (2010) Identification key for young ephyrae: a first step for early detection of jellyfish blooms. Hydrobiologia 645:3-21 
Straehler-Pohl I, Jarms G (2011) Morphology and life cycle of Carybdea morandinii, sp. nov. (Cnidaria), a cubozoan with zooxanthellae and peculiar polyp anatomy. Zootaxa 2755:36-56

Straehler-Pohl I, Toshino S (2015) Carybdea morandinii -New investigations on its life cycle reveal its true genus: Carybdea morandinii Straehler-Pohl \& Jarms, 2011 becomes Alatina morandinii (Straehler-Pohl \& Jarms, 2011). Plankton Benthos Res 10:167-177 Stoecker DK, Johnson MD, de Vargas C, Not F (2009) Acquired phototrophy in aquatic protists. Aquat Microb Ecol 57:279-310

Stoner EW, Layman CA, Yeager LA, Hasset HM (2011) Effects of anthropogenic disturbance on the abundance and size of epibenthic jellyfish Cassiopea spp. Mar Pollut Bull 62:1109-1114

Sugiura Y (1963) On the life-history of Rhizostome medusae I. Mastigias papua L. Agassiz. Annot Zool Jpn 36:194-202

Sugiura Y (1964) On the life-history of Rhizostome medusae II. Indispensability of zooxanthellae for strobilation in Mastigias papua. Embryologia 8:223-233

Sugiura Y (1965) On the life-history of Rhizostome medusae III. On the effects of temperature on the strobilation of Mastigias papua. Biol Bull 128:493-496 Sugiura Y (1969) On the life-history of Rhizostome medusae V. On the relation between zooxanthellae and the strobilation of Cephea cephea. Bull Mar Biol Stn Asamushi 8:227233

Svoboda A, Cornelius PFS (1991) The European and Mediterranean species of Aglaophenia (Cnidaria: Hydrozoa). Zool Verh 274:4-72

Swift HF, Gómez Daglio L, Dawson MN (2016) Three routes to crypsis: Stasis, convergence, and parallelism in the Mastigias species complex (Scyphozoa, Rhizostomeae). Mol Phylogenetics Evol 99:103-115

Thornhill DJ, Daniel MW, LaJeunesse TC, Schmidt GW, Fitt WK (2006) Natural infections of aposymbiotic Cassiopea xamachana scyphistomae from environmental pools of Symbiodinium. J Exp Mar Biol Ecol 338:50-56 
Todd BD, Thornhill DJ, Fitt WK (2006) Patterns of inorganic phosphate uptake in Cassiopea xamachana: A bioindicator species. Mar Pollut Bull 52:515-521

Tokioka T (1964) Occurrences of purplish individuals of Cephea cephea (Forskål) in the vicinity of Seto. Publ Seto Mar Biol Lab 12:149-156

Trench RK (1971) The physiology and biochemistry of zooxanthellae symbiotic with marine coelenterates II. Liberation of fixed ${ }^{14} \mathrm{C}$ by zooxanthellae in vitro. Proc $\mathrm{R}$ Soc London B 177:237-250

Underwood AH, Straehler-Pohl I, Carrette TJ, Sleeman J, Seymour JE (2018) Early life history and metamorphosis in Malo maxima Gershwin, 2005 (Carukiidae, Cubozoa, Cnidaria). Plankton Benthos Res 13:143-153

Venn AA, Loram JE, Douglas AE (2008) Photosynthetic symbiosis in animals. J Exp Bot 59:1069-1080

Verde EA, McCloskey LR (1998) Production, respiration, and photophysiology of the mangrove jellyfish Cassiopea xamachana symbiotic with zooxanthellae: effect of jellyfish size and season. Mar Ecol Prog Ser 168:147-162

Verity PG, Purcell JE, Frischer ME (2011) Seasonal patterns in size and abundance of Phyllorhiza punctata: an invasive scyphomedusa in coastal Georgia (USA). Mar Biol 158:2219-2226

Welsh DT, Dunn RJK, Meziane T (2009) Oxygen and nutrient dynamics of the upside down jellyfish (Cassiopea sp.) and its influence on benthic nutrient exchanges and primary production. Hydrobiologia 635:351-362

Werner B (1973) New investigations on systematics and evolution of the class Scyphozoa and the phylum Cnidaria. Publ Seto Mar Biol Lab 20:35-61

West EJ, Pitt KA, Welsh DT, Koop K, Rissik D (2009) Top-down and bottom-up influences of jellyfish on primary productivity and planktonic assemblages. Limnol Oceanogr $54: 2058-2071$

Wilkerson FP, Kremer P (1992) DIN, DON and $\mathrm{PO}_{4}$ flux by medusa with algal symbionts. Mar Ecol Prog Ser 90:237-250 

Wilkerson FP, Muller Parker G, Muscatine L (1983) Temporal patterns of cell division in natural populations of endosymbiotic algae. Limnol Oceanogr 28:1009-1014 Wittenberg JB (1960) The source of carbon monoxide in the float of the portuguese manof-war Physalia physalis L. J Exp Biol 37:698-705 Yellowlees D, Rees TAV, Leggat W (2008) Metabolic interactions between algal symbionts and invertebrate hosts. Plant Cell Environ 31:679-694 Zeman SM, Corrales-Ugalde M, Brodeur RD, Sutherland KR (2018) Trophic ecology of the neustonic cnidarian Velella velella in the northern California Current during an extensive bloom year: insight from gut contents and stable isotope analysis. Mar Biol 165:120 
Table 1 List of zooxanthellate medusozoan genera found in the literature and inferred in this study (including facultative symbionts). The inference of the presence of zooxanthellae was made for the members of the sub-order Kolpophorae where all the genera on which relevant information is available are zooxanthellate. Unless stated otherwise, it is assumed that all species in each genus may have zooxanthellae. This list is likely far from complete as many groups, particularly in Hydrozoa remain little known. Reports of zooxanthellae presence are classified as follows: "Confirmed": when zooxanthellae have been directly observed and/or studied (e.g. microscopic imagery, zooxanthellae presence used as a taxonomic criterion, measures of photosynthesis available). "Potentially": when authors where unsure that the observed structure were zooxanthellae. "Indirect report": report of the presence of zooxanthellae without direct observation. "Doubtful": indirect reports with contradicting direct observations. Additional indirect evidence (photographs) for the presence of zooxanthellae in some little studied Kolpophorae is discussed in electornic supplementary material (ESM 1)

\begin{tabular}{|c|c|c|}
\hline CLASS, Order, Family & Genus & $\begin{array}{l}\text { Presence of zooxanthellae? } \\
\text { (Reference(s)) }\end{array}$ \\
\hline \multicolumn{3}{|l|}{ CUBOZOA } \\
\hline \multicolumn{3}{|l|}{ Carybdeida } \\
\hline Alatinidae & Alatina & $\begin{array}{l}\text { Confirmed in Alatina morandinii } \\
\text { (Straehler-Pohl and Jarms 2011; Straehler- } \\
\text { Pohl and Toshino 2015) }\end{array}$ \\
\hline Carukiidae & Malo & $\begin{array}{l}\text { Confirmed in Malo maxima (only in a } \\
\text { minority of polyps; Underwood et al. } \\
\text { 2018) }\end{array}$ \\
\hline \multicolumn{3}{|l|}{ HYDROZOA } \\
\hline Anthoathecata & & \\
\hline
\end{tabular}




\begin{tabular}{|c|c|c|}
\hline Capitata incertae sedis & Paulinum & $\begin{array}{l}\text { Potentially (see Kramp } 1961 \text { (as } \\
\text { Dicodonium); Brinckmann-Voss and Arai } \\
\text { 1998) }\end{array}$ \\
\hline \multirow[t]{2}{*}{ Eudendriidae } & Eudendrium* & $\begin{array}{l}\text { Confirmed in some species (Marques et al. } \\
\text { 2000) }\end{array}$ \\
\hline & Myrionema* & Confirmed (Fitt and Cook 2001) \\
\hline Milleporidae & Millepora** & Confirmed (Lewis 2006) \\
\hline \multirow[t]{2}{*}{ Porpitidae } & Porpita & Confirmed (Bouillon et al. 2006) \\
\hline & Velella & $\begin{array}{l}\text { Confirmed (Larson 1980; Bouillon et al. } \\
\text { 2006; Lopes et al. 2016) }\end{array}$ \\
\hline Ptilocodiidae & Hydrichtella* & Indirect report (Muscatine 1974) \\
\hline Stylasteridae & Sporadopora* & Indirect report (Muscatine 1974) \\
\hline \multicolumn{3}{|l|}{ Leptothecata } \\
\hline Agloapheniidae & Aglaophenia* & $\begin{array}{l}\text { Confirmed in some species (Svoboda and } \\
\text { Cornelius 1991) }\end{array}$ \\
\hline Dipleurosomatidae & Dichotomia & Confirmed (Brooks 1903; Bouillon 1984) \\
\hline Haleciidae & Halecium* & $\begin{array}{l}\text { Confirmed in some species (Pagliara et al. } \\
\text { 2000) }\end{array}$ \\
\hline Laodiceidae & Wuvula & Confirmed (Bouillon et al. 1988) \\
\hline Plumulariidae & Pseudoplumaria* & $\begin{array}{l}\text { Confirmed in Pseudoplumaria marocana } \\
\text { (Medel and Vervoort 1995) }\end{array}$ \\
\hline Sertularellidae & Sertularella* & $\begin{array}{l}\text { Indirect report (Muscatine 1974; see also } \\
\text { Calder 1990) }\end{array}$ \\
\hline Sertulariidae & Dynamena* & Potentially (Galea and Ferry 2015) \\
\hline Thyroscyphidae & Symmetroscyphus* & Confirmed (Calder 1990) \\
\hline
\end{tabular}




\begin{tabular}{|c|c|c|}
\hline Siphonophorae & & \\
\hline Physaliidae & Physalia & $\begin{array}{l}\text { Doubtful (Wittenberg } 1960 \text { but see Lopes } \\
\text { et al. 2016) }\end{array}$ \\
\hline \multicolumn{3}{|l|}{ SCYPHOZOA } \\
\hline \multicolumn{3}{|l|}{ Coronatae } \\
\hline Linuchidae & Linuche & $\begin{array}{l}\text { Confirmed (Ortiz-Corp's et al. 1987; } \\
\text { Kremer et al. 1990) }\end{array}$ \\
\hline Nausithoidae & Nausithoe & $\begin{array}{l}\text { Confirmed in some species (Werner 1973; } \\
\text { Silveira and Morandini 1997) }\end{array}$ \\
\hline \multicolumn{3}{|l|}{ Rhizostomeae } \\
\hline Catostlylidae & Catostylus & $\begin{array}{l}\text { Doubtful (Muscatine } 1974 \text { but see Pitt et } \\
\text { al. 2005) }\end{array}$ \\
\hline Rhizostomatidae & Rhizostoma & $\begin{array}{l}\text { Doubtful (Trench } 1971 \text { but see Fuentes et } \\
\text { al. 2011) }\end{array}$ \\
\hline $\begin{array}{l}\text { Cassiopeidae } \\
\text { (Kolpophorae) }\end{array}$ & Cassiopea & $\begin{array}{l}\text { Confirmed (Freudenthal 1962; Mergner } \\
\text { and Svoboda 1977; Verde and McCloskey } \\
\text { 1998) }\end{array}$ \\
\hline \multirow[t]{3}{*}{$\begin{array}{l}\text { Cepheidae } \\
\text { (Kolpophorae) }\end{array}$} & Cephea & Confirmed (Sugiura 1969) see also ESM 1 \\
\hline & Cotylorhiza & Confirmed (Kikinger 1992) see also ESM 1 \\
\hline & Marivagia & $\begin{array}{l}\text { No photographic evidence of the presence } \\
\text { of zooxanthellae in the medusa (ESM 1) - } \\
\text { inference: zooxanthellae likely present in } \\
\text { the polyp as in close relatives }\end{array}$ \\
\hline
\end{tabular}




\begin{tabular}{|l|l|l|}
\hline & Netrostoma & $\begin{array}{l}\text { Confirmed (Straehler-Pohl and Jarms } \\
\text { 2010) see also ESM 1 }\end{array}$ \\
\hline $\begin{array}{l}\text { Mastigiidae } \\
\text { (Kolpophorae) }\end{array}$ & Mastigias & $\begin{array}{l}\text { Confirmed (Sugiura 1964; McCloskey et al. } \\
\text { 1994) }\end{array}$ \\
\hline $\begin{array}{l}\text { Thysanostomatidae } \\
\text { (Kolpophorae) }\end{array}$ & Thysanostoma & Photographic evidence for the presence of \\
\hline $\begin{array}{l}\text { Versurigidae } \\
\text { (Kolpophorae) }\end{array}$ & Versuriga & $\begin{array}{l}\text { Photographic evidence for the presence of } \\
\text { zooxanthellae available (ESM 1) }\end{array}$ \\
\hline$?$ & Bazinga & Confirmed (Gershwin and Davie 2013) \\
\hline & & \\
\hline
\end{tabular}

${ }^{*}=$ groups with no medusae phase (see Bouillon et al. 2006). ${ }^{* *}=$ group with short lived medusae phase (see Soong and Cho 1998)

Table 2 Presence of zooxanthellae along the life-cycle in some species of zooxanthellate jellyfish. Brackets indicates a state inferred from closely related species but without direct confirmation found in the literature

\begin{tabular}{|l|l|l|l|l|l|}
\hline Species & Planula & Polyp & Ephyra & Medusa & Reference(s) \\
\hline CUBOZOA & & & & & \\
\hline Carybdeida & & & & & \\
\hline Alatina morandinii & $?$ & present & N/A & present & $\begin{array}{l}\text { Straehler-Pohl and } \\
\text { Jarms 2011; Straehler- } \\
\text { Pohl and Toshino 2015 }\end{array}$ \\
\hline
\end{tabular}




\begin{tabular}{|c|c|c|c|c|c|}
\hline Malo maxima* & $?$ & present & $\mathrm{N} / \mathrm{A}$ & $?$ & Underwood et al. 2018 \\
\hline \multicolumn{6}{|l|}{ HYDROZOA } \\
\hline \multicolumn{6}{|l|}{ Anthoathecata } \\
\hline Porpita porpita & $?$ & present & $\mathrm{N} / \mathrm{A}$ & present & Bouillon et al. 2006 \\
\hline Velella velella & $?$ & present & N/A & present & $\begin{array}{l}\text { Larson 1980; Bouillon } \\
\text { et al. } 2006\end{array}$ \\
\hline \multicolumn{6}{|l|}{ Leptothecata } \\
\hline Wuvula fabietii & $?$ & $?$ & $\mathrm{~N} / \mathrm{A}$ & present & Bouillon et al. 1988 \\
\hline \multicolumn{6}{|l|}{ SCYPHOZOA } \\
\hline \multicolumn{6}{|l|}{ Coronatae } \\
\hline Linuche unguiculata & present & present & present & present & $\begin{array}{l}\text { Ortiz-Corp's et al. 1987; } \\
\text { Montgomery and } \\
\text { Kremer 1995; Silveira } \\
\text { and Morandini } 1998\end{array}$ \\
\hline Nausithoe aurea & $?$ & present & present & present & $\begin{array}{l}\text { Silveira and Morandini } \\
1997\end{array}$ \\
\hline \multicolumn{6}{|l|}{ Rhizostomeae } \\
\hline Cassiopea spp. & absent & present & present & present & $\begin{array}{l}\text { Ludwig 1969; Hofmann } \\
\text { et al. 1996; Verde and } \\
\text { McCloskey } 1998\end{array}$ \\
\hline Cephea cephea* & absent & present & present & absent & Sugiura 1969 \\
\hline Cotylorhiza tuberculata & absent & present & present & present & Kikinger 1992 \\
\hline
\end{tabular}




\begin{tabular}{|c|c|c|c|c|c|}
\hline Mastigias papua** & absent & present & present & present & $\begin{array}{l}\text { Sugiura } 1963 \text {; Sugiura } \\
1964 \text {; Dawson et al. } \\
2001\end{array}$ \\
\hline Phyllorhiza punctata** & (absent) & present & present & present & $\begin{array}{l}\text { Bolton and Graham } \\
2004 \text {; Schiariti et al. } \\
2014\end{array}$ \\
\hline
\end{tabular}

$1 ?=$ unknown. ${ }^{*}=$ species where presence of the symbiont is facultative. ${ }^{* *}=$ species with

2 some populations without zooxanthellae. N/A = not applicable (cubozoans and hydrozoans 3 do not have ephyra) 
Review of the diversity, traits, and ecology of zooxanthellate jellyfishes (Electronic Supplementary Material)

Nicolas Djeghri, Philippe Pondaven, Herwig Stibor, Michael N Dawson

ESM 1: Photographic evidence of zooxanthellae presence or absence in less studied Kolpophorae medusae

\section{Method}

In the absence of samples that could be tested using a suite of modern techniques (see main text) possible presence of zooxanthellae was assessed using photographs of the less studied genera (or species) of Kolpophorae. Photographs were searched for in scientific publications (as priority) and online. These genera and species belong to the families Cepheidae, Thysanostomatidae and Versurigidae. Brown coloration was considered as potential evidence for the presence of zooxanthellae. Absence of brown coloration was considered as evidence for few or no zooxanthellae.

The genera and species investigated for photographs were the following:

Cepheidae: Cephea spp., Cotylorhiza erythraea, Marivagia stellata, Netrostoma spp.

Thysanostomatidae: Thysanostoma spp.

Versurigidae: Versuriga spp.

Importantly, this method does not allow us to conclude that a species is or is not zooxanthellate as photos generally are of insufficient resolution to see zooxanthellate and, also, zooxanthellae may still be present in the polyp. 


\section{Results and Discussion}

Cepheidae:

Cephea spp.: The photographs show generally very clear medusae, with possibly a few zooxanthellae in the tip of oral arms (Cruz-Riveira and El-Regal 2015; Gul et al. 2015a, b). Zooxanthellae are however present in the polyp and ephyra (Sugiura 1969). This supports the conclusion of Sugiura (1969) stating that Cephea cephea loose most of its symbionts during the medusa phase.

See also:

http://thescyphozoan.ucmerced.edu/Syst/Rhi/C cephea i.html

Cotylorhiza eythraea: Photographs of both clear and brownish individuals found (Galil et al. 2016) suggesting that this species is a facultative symbiont at the medusa stage. Zooxanthellae apparently present in oral arms.

Marivagia stellata: The photographs found show only very clear individuals (Galil et al. 2010) suggesting that this species is not zooxanthellate at the medusa stage (zooxanthellae may still be present in polyps and ephyra, see Cephea spp. and Netrostoma spp.).

Netrostoma spp.: The photographs found show very clear individuals, with possibly a few zooxanthellae in the tip of oral arms (Gul et al. 2015a). Zooxanthellae present in polyp and ephyra (Straehler-Pohl and Jarms 2010). This suggests that this genus loses most of its symbionts at the medusae stage, as does its close relative Cephea spp.

Thysanostomatidae:

Thysanostoma spp.: No color photograph found in scientific papers. Online photographs suggest the presence of zooxanthellae in oral arms and coronal muscle:

https://fr.wikipedia.org/wiki/Thysanostoma\#/media/File:Thysanostoma loriferum Maldives $\underline{. J P G}$ 
http://doris.ffessm.fr/Especes/Thysanostoma-cf.-loriferum-Thysanostome-bleue-

\section{$\underline{4883 / \text { (rOffset)/0 }}$}

http://doris.ffessm.fr/Especes/Thysanostoma-thysanura-Thysanostome-rouge-

\section{$\underline{3539 /(\text { rOffset }) / 1}$}

http://thescyphozoan.ucmerced.edu/Syst/Rhi/T Thysanura i.html

Versurigidae:

Versuriga spp.: Photographs of brown individuals (Sun et al. 2018) suggest this genus is zooxanthellate. Zooxanthellae apparently present in oral arms and along the coronal muscle. Another photograph shows a pale individual, suggesting that the genus may be a facultative symbiont:

http://thescyphozoan.ucmerced.edu/Syst/Rhi/V anadyomene i.html

\section{References}

Cruz-Rivera E, El-Regal MA (2015) A bloom of an edible scyphozoan jellyfish in the Red Sea. Mar Biodivers 46:515-519

Galil BS, Gershwin L-A, Douek J, Rinkevich B (2010) Marivagia stellata gen. et sp. nov. (Scyphozoa: Rhizostomeae: Cepheidae), another alien jellyfish from the Mediterranean coast of Israel. Aquat Invasions 5:331-340

Galil BS, Gershwin L-A, Zorea M, Rahav A, Rithman SB-S, Fine M, Lubinevsky H, Douek J, Paz G, Rinkevich B (2016) Cotylorhiza erythaea Stiasny, 1920 (Scyphozoa: Rhizostomeae: Cepheidae), yet another erythreaean jellyfish from the Mediterranean coast of Israel. Mar Biodivers 47:229-235

Gul S, Moazzam M, Morandini AC (2015a) Crowned jellyfish (Cnidaria: Scyphozoa: Rhizostomeae: Cepheidae) from waters off the coast of Pakistan, northern Arabian Sea. Check List 11:1551 
Gul S, Morandini AC, Moazzam M (2015b) First record of the crowned jellyfish

Netrostoma coerulescens (Cnidaria: Scyphozoa) from Pakistani waters. Mar Biodivers Rec 8:e156

Straehler-Pohl I, Jarms G (2010) Identification key for young ephyrae: a first step for early detection of jellyfish blooms. Hydrobiologia 645:3-21

Sugiura Y (1969) On the life-history of Rhizostome medusae V. On the relation between zooxanthellae and the strobilation of Cephea cephea. Bull Mar Biol Stn Asamushi 8:227233

Sun T, Dong Z, Li Y (2018) Versuriga anadyomene, a newly recorded scyphozoan jellyfish (Scyphozoa: Rhizostomae) in Chinese waters. J Oceanol Limnol 37:266-272 